\title{
A REVIEW OF THE GENUS SCHISTURA IN PAKISTAN WITH DESCRIPTION OF NEW SPECIES AND SUBSPECIES (PISCES, COBITIDAE, NOEMACHEILINAE)
}

\author{
by \\ MUHAMMAD R. MIRZA \\ Government College, Department of Zoology, Labore, Pakistan \\ and \\ TEODOR T. NALBANT \& PETRU M. BANARESCU \\ Institute of Biology, Department of Taxonomy and Evolution, \\ Spl. Independenței 296, 77748 Bucuresti, Romania
}

\section{ABSTRACT}

The genus Schistura in Pakistan is reviewed: 20 species (of which 8 are new) and 1 subspecies (new) arranged in 3 species groups are recognized.

\section{RESUME}

Un aperçu du genre Schistura en Pakistan est donné: on y reconnaît 20 espèces (dont 8 nouvelles) et 1 sous-espèce (nouvelle) placées en 3 groupes d'espèces.

\section{INTRODUCTION}

A great number of noemacheiline loaches are known from various areas of Pakistan (Günther, 1889; Zugmayer, 1912; Hora, 1923, 1933 a \& b; Ahmad \& Mirza, 1963; Banarescu \& Mirza, 1965, 1972; Mirza, Banarescu \& Nalbant, 1969, 1970; Mirza, 1972, 1973, 1975, 1976; Omer \& Mirza, 1975; Mirza \& Awan, 1976; Ahmad, Khan \& Mirza, 1976). Their number is constantly increasing, almost each collection revealing new species.

Until recently, most noemacheiline loaches described, and all those recorded from Pakistan were included within the composite genus Noemacheilus. In some recent papers, however, several subgenera are recognized and it was suggested that most of these actually deserve full generic status. Since a critical comparative study of most species of the subfamily is in an advanced stage ("The system of Noemacheilinae", Banarescu \& Nalbant, in preparation), it is already possible to split this too large genus into several, more natural units.
The noemacheiline loaches from Pakistan belong to four genera: Noemacheilus (up to now only N. corica), Acanthocobitis (only A. botia), Triplophysa (i.e., the species with High Asian affinities: griffitbi, brabui, naziri, stoliczkai, akbtari, choprai) and Schistura, which includes most species from the Indus basin and from the inland drainages in the western areas of Pakistan.

The present paper deals only with the species of Schistura. All are reviewed, supplementary data about their distribution, and main distinctive features of each of them are mentioned, the new species being described and illustrated.

\section{MATERIAL}

Most specimens on which this study is based were collected in Pakistan by the first author and his collaborators. The holotypes and some of the paratypes belong to the collections of the Institute of Biology (Institutul de Stiinte Biologice) in Bucharest (ISBB); other paratypes are in the Zoölogisch Museum, Amsterdam (ZMA) and in the private collection of the first author. Comparative material was received on loan from the British Museum (Natural History) (BMNH) and from Dr. P.-G. Bianco, L'Aquila, Italy.

\section{SYSTEMATIC ACCOUNT}

Genus Schistura McClelland, 1839

Type-species: Cobitis (Schistura) rupecula McClelland, by subsequent designation (Jordan, 1919: 195). 
A complete diagnosis and definition of this genus, the most complex and most variable within the subfamily, and also the largest or second largest, will be given in another paper (Banarescu \& Nalbant, in preparation); its main characters were already mentioned in certain previous publications (Banarescu \& Nalbant, 1966, 1968, 1974).

A difficult problem is the nomenclatorial status of the genus. It was proposed by McClelland (1839) as subgenus of Cobitis. The original diagnosis is incomplete; some characters mentioned apply to botiine, others to noemacheiline loaches (e.g. "with or without suborbitar spines"). McClelland (: 440-443) lists the following species as Schistura: montana, zonata, rupecula, ocellata, savona, punctata, subfusca, scaturigina. All, except perhaps ocellata (being unidentifiable) are Noemacheilinae; the first three and last two taxa are recorded in previous papers of the authors as Schistura. Much confusion raises from the fact that in the short diagnosis of the species, McClelland (: 306-309), lists as Schistura some more species besides the eight mentioned above: dario, geta (misprint for geto) grandis, balgara, aculeata; the three first ones actually are Botiinae. But in the main text $(: 443-445)$ these species are listed under Cobitis (dario and geta) and Botia (grandis). McClelland (: 443) even writes:

"So many divisions of the Loaches have been proposed, and so many names to designate those divisions, that I feel some doubt in recommending the generic term Hymenphysa for the following three species, which are distinguished from all others by the presence of an abdominal natatory bladder, separated into lobes by a longitudinal septum". Follows the description of Cobitis dario, C. geta and Botia grandis.

Modern authors are unanimous in accepting that in these few lines, McClelland established the taxon Hymen (o)physa, presently accepted as a valid subgenus of Botia.

Among the authors from the 19th century, Valenciennes (1846: 9-12) considers Scbistura as a synonym of Cobitis, and Bleeker (1863: 2) as a synonym of Botia. These viewpoints cannot be accepted, since the name Cobitis is restricted to the taenia group of species and on the other hand, no species presently assigned to Botia are listed under Schistura in McClelland's main text (: 439$445)$; on the contrary, he clearly assigned the species dario, geta, and grandis to Hymen(o)physa. We therefore accept Jordan's (1919: 195) designation of rupecula (one of the eight species ascribed by McClelland to this subgenus) as generotype.

Several groups of species can be recognized within Schistura. The type-species, rupecula, belongs to a group characterized by: depressed head; scaled body; complete or almost complete lateral line; truncate, emarginate, or slightly forked caudal fin; apparently no sexual dimorphism; toothlike prolongation of the upper jaw (processus dentiformis) strongly developed and a corresponding incision on the lower jaw. This group includes mainly species from the Ganges and Brahmaputra basins, Burma, the rivers of Thailand and the southern parts of East Asia, northwards to the upper Yangtze River; it does not occur in Pakistan and apparently not elsewhere in the Indus basin.

The species from Pakistan belong to the following three groups:

\section{Group alepidota-pakistanica}

The species of this group are characterized by: a large size; depressed head; totally scaleless body; no sexual dimorphism; rather long lateral line, reaching at least to below dorsal fin; truncate or emarginate caudal fin; strongly developed processus dentiformis and usually a corresponding incision on the lower jaw.

The group is endemic to the Indus basin in Pakistan and Afghanistan; it differs from the rupecula group above all in the absence of scales and usually shorter lateral line (in the rupecula group this is always almost complete). It includes four species:

Schistura alepidota (Mirza \& Banarescu, 1970). Fig. 2.

Nemacheilus rupicola inglisi (non Hora); Ahmad \& Mirza, 1963: 75 (Madyan River, Swat River basin, Pakistan).

Noemacheilus rupecola alepidotus Mirza \& Banarescu, in Mirza, Banarescu \& Nalbant, 1970: 55, fig. 10 (Madyan River; further localities: Marghzar, Mingoara, Shiner, all in the Swat River basin; not Panjar, Jhelum River basin). 

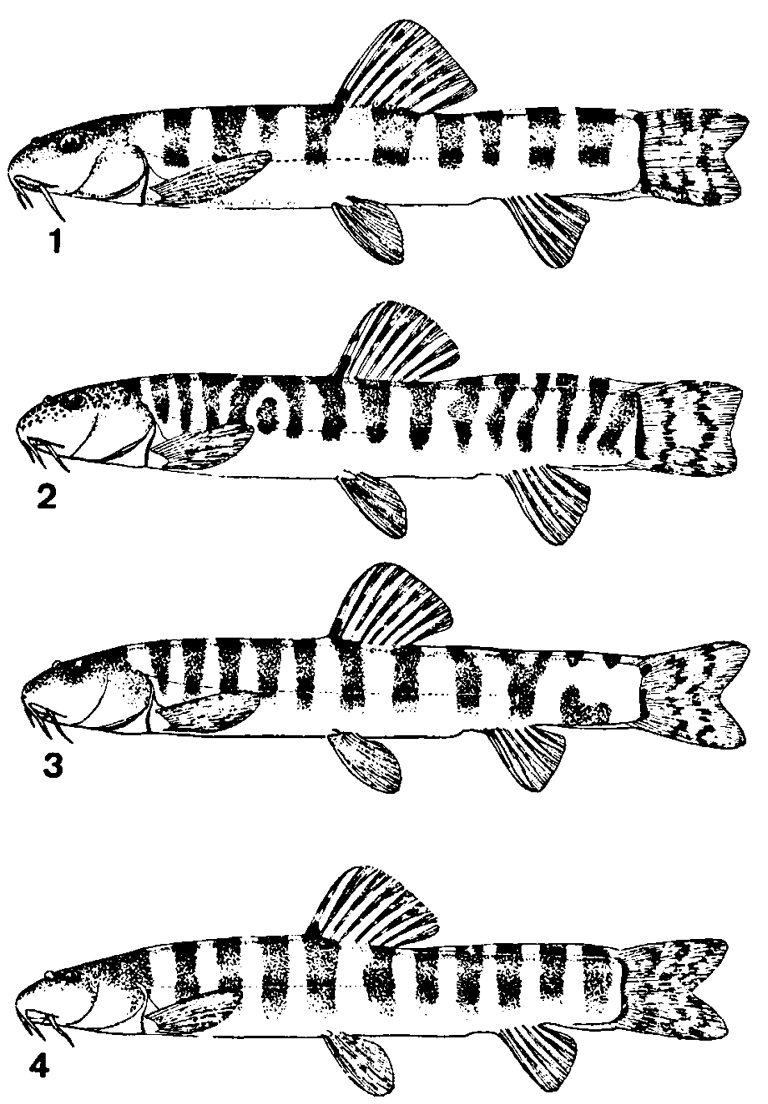

Fig. 1. Schistura pakistanica, ISBB 2005, holotype, from the Zhob River, Hindubagh. Fig. 2. S. alepidota, ISBB 1356, holotype, from the Madyan River, Swat drainage. Fig. 3. S. nalbanti, ISBB 2490, holotype, from the Jhelum River, Rawlakot, Azad Kashmir. Fig. 4. S. paludani, Zoological Museum Copenhagen, Pisces, coll. no. 2801, holotype, from the Pech River, tributary of the Kabul River at Gusalek, Afghanistan.

The species is characterized by: $12-15$ crossbars ( $\mathrm{M}=$ ca. 13 or 14$)$; truncate caudal fin; a rather well-developed adipose crest in the posterior part of the caudal peduncle; lateral line of variable length, reaching below dorsal fin, above anal fin or to an intermediate point; large roundish spots on upper face of head; a continuous stripe on the caudal fin base (of irregular, more or less undulated shape and variable width); processus dentiformis not notched medially.

Range. - The species was described from the Madyan River and three other localities in the Swat River basin; this is a tributary of the lower Kabul River, a right tributary of the Indus. Further specimens were obtained later from two more localities: Hangu on the Kohat Toi River (a right tributary of the Indus south of the Kabul River) and Abbottabad on the Dor River (a left tributary of the Indus, its confluence lying east-northeast from that of the Kabul River) (map 1). Probably the species also occurs in the lower Kabul River, as well as in the Indus proper, at least between the confluences of Dor, Kabul, and Kohat Toi rivers. The few specimens available from Hangu and Abbottabad are small; we therefore could not make out if there are differences with those from the Swat River basin.

\section{Schistura pakistanica (Mirza \& Banarescu, 1969). Fig. 1.}

Noemacheilus pakistanicus Mirza \& Banarescu, in Mirza, Banarescu \& Nalbant, 1969: 97, figs. 1.3 (Hindubagh, now Muslimbagh, Zhob River basin).

Noemacheilus rhadineus (non Regan) Mirza, 1972: 173 (Fort Sandeman, now Zhob City, Zhob River basin).

Noemacheilus cristatus (non Berg) Mirza, 1975: 160, 170-171.

This species has 9-10 broad crossbars, a truncate or slightly emarginate caudal fin with roundish lobes; upper face of head uniformly dark, without distinct spots; stripe on the base of the caudal fin continuous, narrower than in alepidota, and either complete (extending from the dorsal to the ventral side) or developed in the middle only; processus dentiformis in some specimens notched in the middle; lateral line almost complete, its end always closer to caudal fin base than to end of anal fin; an adipose keel on the caudal peduncle. Comparison of the original description of this species with that of $S$. alepidota reveals some differences in body proportions, above all the longer snout in pakistanica.

Besides the holotype and paratypes, a few more specimens were obtained, all from Zhob City, 77.0-98.0 $\mathrm{mm}$ standard length.

Range. - This species is probably endemic to the Zhob River, a tributary of the Gomal River, a right tributary of the middle Indus, south of the Swat, Kohat Toi and Kurram rivers (map 1).

Schistura nalbanti (Banarescu \& Mirza, 1972) Fig. 3.

Noemacheilus rupecola alepidotus Mirza \& Banarescu, in Mirza, Banarescu \& Nalbant, 1970: 55 (partim: Panjar, 
Jhelum River basin; not the type-locality and not other localities in the Swat River basin).

Noemacheilus alepidotus nalbanti Banarescu \& Mirza, 1972: 121, figs. 1-2 (Rawlakot, Azad Kashmir, Jhelum River basin).

This loach was originally described as a subspecies of alepidota, the original description mentioning a single differential character: fewer crossbars. Actually, a critical comparison of the four forms of the alepidota group revealed more differences, nalbanti being even closer to $S$. paludani from the Kabul River basin than to alepidota.

S. nalbanti has 10-12, rarely 13 crossbars (average value 11 in both the Rawlakot and Panjar populations); the caudal fin is evidently emarginate; the upper face of the head is uniformly dark and unspotted; the lateral line is shorter, usually not reaching near the caudal fin base; the processus dentiformis is much stronger than in both alepidota and pakistanica; the adipose crest on the caudal peduncle is on the contrary weaker than in these two species; the dark brown stripe on the base of the caudal fin is not continuous as in the two preceding species, but always divided in a dorsal spot, and a much longer, lower fragment that extends from above the middle of the fin to the ventral side.

Range. - Up to now, S. nalbanti is known only from the basin of the Jhelum River, a northern tributary of the Sutlej River, left tributary of the

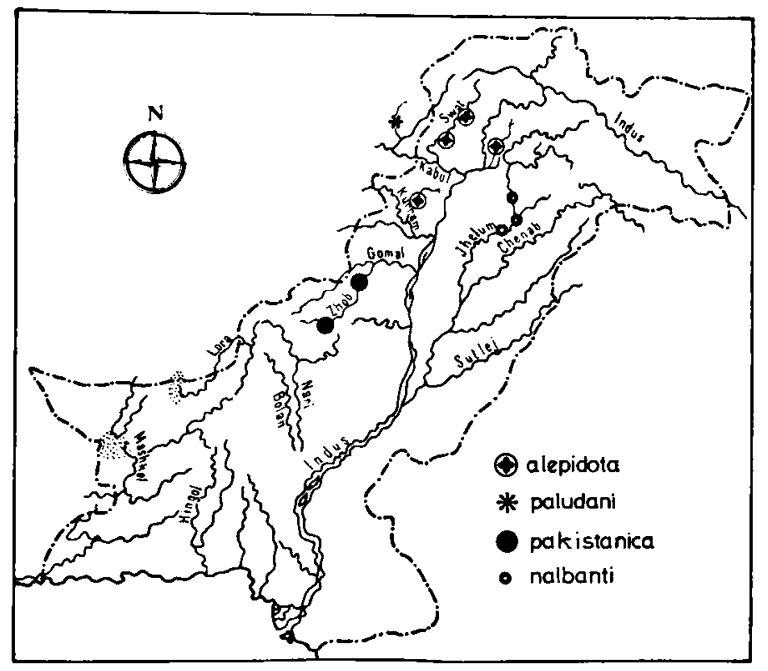

Map 1. Distribution of Schistura alepidota, S. paludani, S. pakistanica and $S$. nalbanti.

middle Indus; it is the easternmost species of the group (map 1).

Schistura paludani (Banarescu \& Nalbant, 1966). Fig. 4.

Noemacheilus sargadensis paludani Banarescu \& Nalbant, 1966: 167, figs. 9-10, pl. XXI figs. 1-2 (Pech River, Kabul River basin, at Gusalek, northeastern Afghanistan).

This loach was initially described as a subspecies of the little-known (and by the time not available) sargadensis from southeastern Iran. We recently received specimens of sargadensis from the $\mathrm{Kul}$ River, Iran, collected by Dr. P.-G. Bianco. This river lies close to the Sargad River, type-locality of sargadensis. These specimens perfectly correspond to the original description of sargadensis (A. M. Nikolski, 1900: 415) and also to the illustration of the type-specimen by Berg (1949 b: 841 , fig. 55). The true sargadensis has a scaled body, a more deeply emarginate (almost forked) caudal fin, a feeble processus dentiformis, and irregular crossbars; it belongs to another species group of Schistura.

S. paludani is a distinct species of the alepidota group; it has 8-14 crossbars, an emarginate caudal fin, a rather strong adipose crest on the caudal peduncle, a strong processus dentiformis; the lateral line reaches to above the anal fin, being interrupted in several places between the dorsal and anal fins; the dark stripe on the caudal fin base is continuous.

$S$. paludani is closest to $S$. nalbanti; both species have, contrary to alepidota and pakistanica, an emarginate caudal fin. It differs from nalbanti in having a stronger adipose crest, a continuous dark stripe on the caudal fin base and in different body proportions, e.g.:

Predorsal distance
Preventral distance
P.V distance
Caudal peduncle
Length of pectoral fin
Length of ventral fin
Length of caudal fin
Maxillar barbel
Eye diameter
Eye diameter

\section{paludani} $48.1-50.5 \%$ of SL $50.1-52.1 \%$ of SL $28.6-30.8 \%$ of SL $15.6-17.0 \%$ of SL $16.6-21.0 \%$ of SL $14.9-18.5 \%$ of SL $18.3-20.6 \%$ of SL 4.6- $7.6 \%$ of SL $12.5-17.1 \%$ of head $50.0-56.0 \%$ of interorbital nalbanti $51.0-55.8 \%$ $51.3 .55 .8 \%$ $29.0-32.2 \%$ $12.7-15.7 \%$ $18.6-22.2 \%$ $15.9-19.1 \%$ $18.8-24.6 \%$ 5.9. $8.8 \%$ $14.5-21.0 \%$ $57.5 \cdot 66.7 \%$ 
Other body proportions (depth, least depth, head length, etc.) are similar in both species.

Range. - This species is up to now only known from the Pech River in the basin of the Kabul River, northeastern Afghanistan near the frontier with Pakistan (map 1). Since the Kabul River also flows through Pakistan, the range of paludani probably includes part of this country too.

\section{Group kessleri-lindbergi}

The species of this group are characterized by: a small size; rather compressed head; body totally devoid of scales, or with a quite reduced scaled area on the caudal peduncle; lateral line short, not reaching to the middle of the body; caudal fin emarginate to slightly forked; processus dentiformis reduced; no sexual dimorphism; dorsal fin with seven branched rays.

The range of this group extends from Turk- menia and eastern Iran to the Baluchistan Province and the Indus basin in Pakistan. It includes two species, both also found in Pakistan (map 2).

Schistura kessleri kessleri (Günther, 1889). Figs. 5-8.

Nemacbilus kessleri Günther, 1889: 109 (Nushki, Pishin Lora River basin, Afghanistan); Hora, 1933a: 187, fig. 2, pl. V fig. 3 (Nushki; Quetta and Pishin districts in northern Baluchistan); Berg, 1949a: 877, fig. 623 (northern Baluchistan, eastern Iran and Kushka River).

Noemacheilus kessleri; Banarescu \& Nalbant, 1966: 171, fig. 11 and pl. XXI figs. 3-4 (Ghazni River, Helmand basin; Jannichel, Kabul basin; Quetta, Pishin Lora basin).

Further available specimens from Afghanistan (besides those listed by Banarescu \& Nalbant, 1966): BMNH 1886. 9.21.177-178, from Nushki, 38.8 and $45.0 \mathrm{~mm}$ standard length; the largest specimen is here selected as lectotype (fig. 5).

Pakistan specimens are available from: Quetta, Pishin Lora basin; Panjgur on the Rakhshan
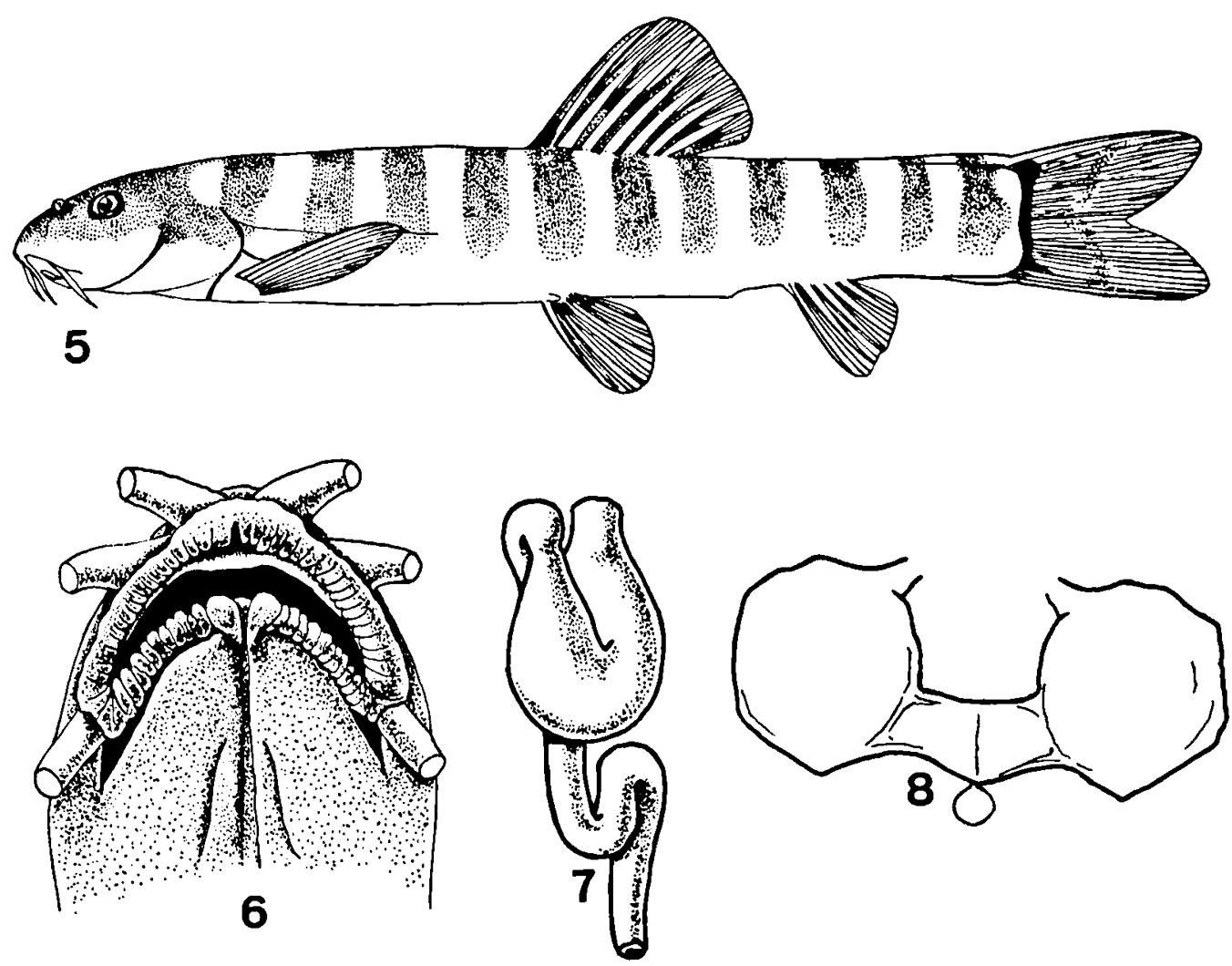

Fig. 5. Schistura kessleri kessleri, BMNH 1886.9.21.177, lectotype, from the Nushki River, Pishin Lora basin, Afghanistan. Fig. 6. Do., mouth of lectotype. Fig. 7. Do., digestive tract of paralectotype, BMNH 1886.9.21.178. Fig. 8. Do., air bladder capsule of paralectotype. 
River, Hamun-i-Mashkel lake basin; Kalat in Central Brahui mountain range, basin of Bodo River, inner drainage (map 2).

The papers mentioned in the synonymy of the species include a complete description and illustration of $S$. kessleri kessleri, having a low body and caudal peduncle (compared to $S$. lindbergi) and being totally devoid of scales.

Range. - The subspecies probably also occurs, besides the river basins mentioned above, in the basins of the Bolan and Nari rivers. Outside Pakistan, it ranges in the Pishin Lora basin in Afghanistan, and in the Murghab basin in Afghanistan and Turkmenistan (in this basin probably as a distinct subspecies, S. k. turcomanus (G. Nikolski, 1947)).
Schistura kessleri lepidocaulis Mirza \& Nalbant, n. subsp. Figs. 9-13.

Holotype: ISBB $3366,43.0 \mathrm{~mm}$ standard length $(44.0 \mathrm{~mm}$ to the end of the scales), Parachinar, basin of the Kurram River, a right tributary of the Indus.

Paratypes: ISBB 3367, ZMA 116.441 (2), and Mirza's private collection, four specimens in all, $32.5-33.0 \mathrm{~mm}$; Sün Sakesar, a closed valley on a left tributary of the Indus, opposite to the Kurram River.

Derivatio nominis. - After $\lambda \varepsilon \pi i \varsigma^{\prime}=$ scale and caulis $=$ peduncle, alluding to the occurrence of a few scales on the caudal peduncle.

Diagnosis. - A subspecies of Schistura kessleri having isolated scales on a reduced area of the caudal peduncle.

Description. -

D $3 / 7$; A 2/5; P 1/9; V 2/6.

General habitus and body proportions very similar to S. kessleri kessleri.
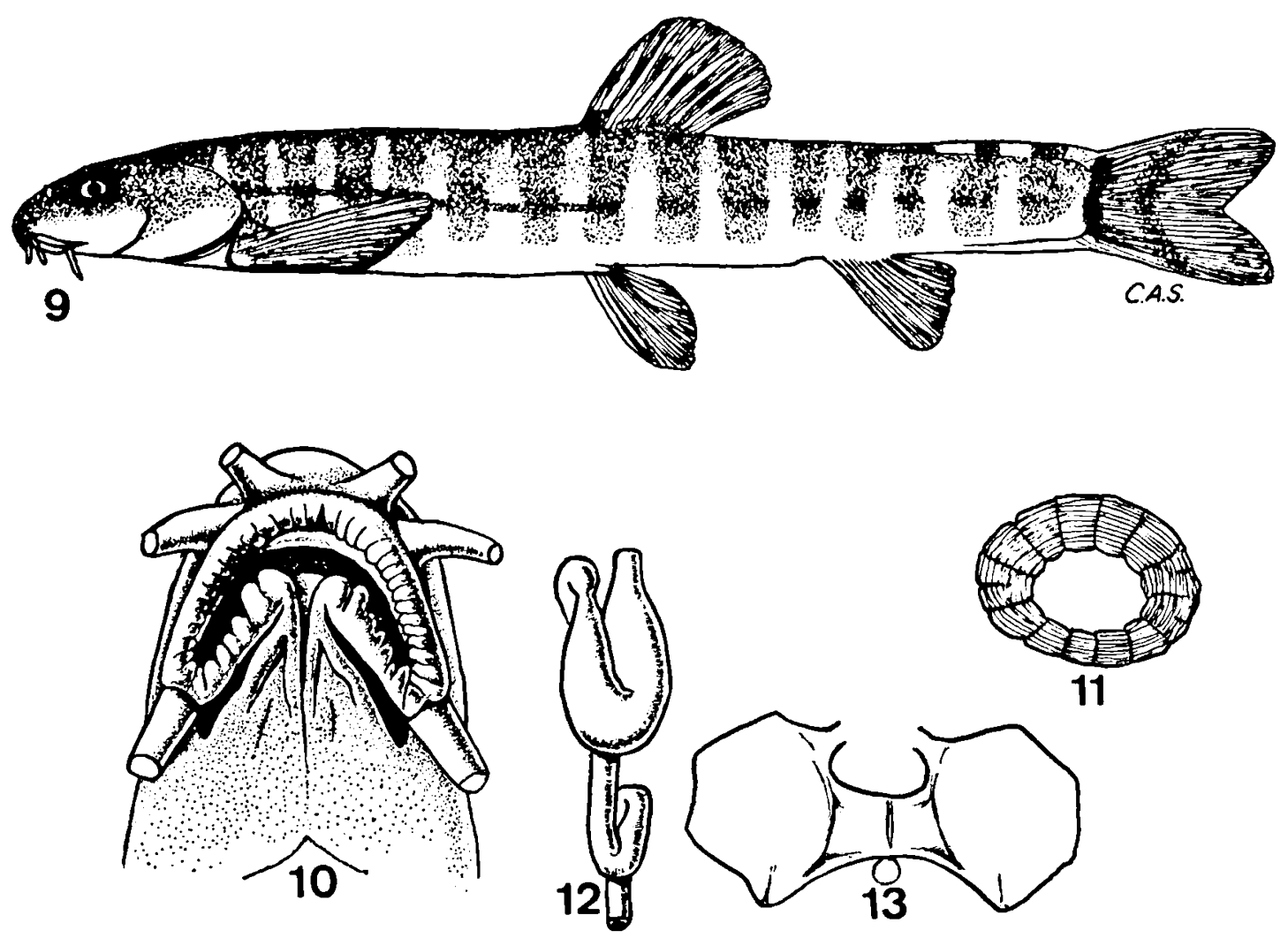

Fig. 9. Schistura kessleri lepidocaulis n. subsp., ISBB 3366, holotype, from the Kurram River, Parachinar. Fig. 10. Do., mouth of holotype. Fig. 11. Do., scale from the caudal peduncle of the holotype. Fig. 12. Do., digestive tract of a paratype, ISBB 3367. Fig. 13. Do., air bladder capsule of a paratype, ISBB 3367. 
Body depth 12.7-14.5\% of standard length (13.5\% in the holotype); caudal peduncle length $14.4-18.4 \%$ (14.4\%); least depth 10.2-12.0\% $(11.1 \%)$; predorsal distance $50.5-55.0 \%$ $(52.4 \%)$; preventral distance $49.0-55.0 \%$ (52.4\%); preanal distance $72.9-79.0 \%(76.5 \%)$; pectoral-ventral distance $30.8-34.0 \%$ (34.8\%); ventral-anal distance $24.0-26.2 \%(25.6 \%)$; length of pectoral fin $18.5-24.6 \%(21.4 \%)$; length of ventral fin $18.3-23.1 \%$ (18.3\%); base of dorsal fin $11.7-13.5 \%(13.5 \%)$; height of dorsal fin 16.9-19.1\%; base of anal fin 7.9-9.1\% (8.1\%); height of anal fin 14.3-16.9\% (15.8\%); length of head 18.9-23.1\% (19.8\%); length of snout $6.3-7.7 \%(6.3 \%)$; eye diameter $3.7-4.6 \%$ $(3.7 \%)$. Snout $29.6-33.3 \%$ of head $(31.8 \%$ in holotype); eye diameter $18.6-21.4 \%$ of head $(18.7 \%)$ and $55.0-75.0 \%$ of interorbital width $(55.0 \%)$.

Origin of dorsal fin closer to caudal base than to tip of snout; origin of ventral fins exactly under that of the dorsal one (most specimens) or very slightly behind it.

Lateral line incomplete, ending before dorsal fin or in front of it. Most of the body scaleless; a reduced area, on the sides of the caudal peduncle, covered by isolated scales (fig. 11). Peritoneum dark brown. Lips, intestine, and air bladder capsule as in S. kessleri kessleri (figs. 8, 13).

Colour pattern. - Body light yellowish; 14 or 15 broad brownish crossbars extend from the dorsal almost to the ventral side; they are separated by broader light interspaces. A well-marked dark brown spot at the base of dorsal fin insertion; a row of minute spots on the dorsal fin; other fins unspotted.

4 in

Range. - This new subspecies was found in two rather distant localities: the basin of the Kurram River, a right tributary of the Indus (south of the Kabul and north of the Gomal rivers) and Sün Sakesar, a valley on the left side of the Indus, just opposite the Kurram River; this valley is drained by several small streams without outlet to the Indus. This range lies rather far north- and eastwards from that of the nominal subspecies (map 2).

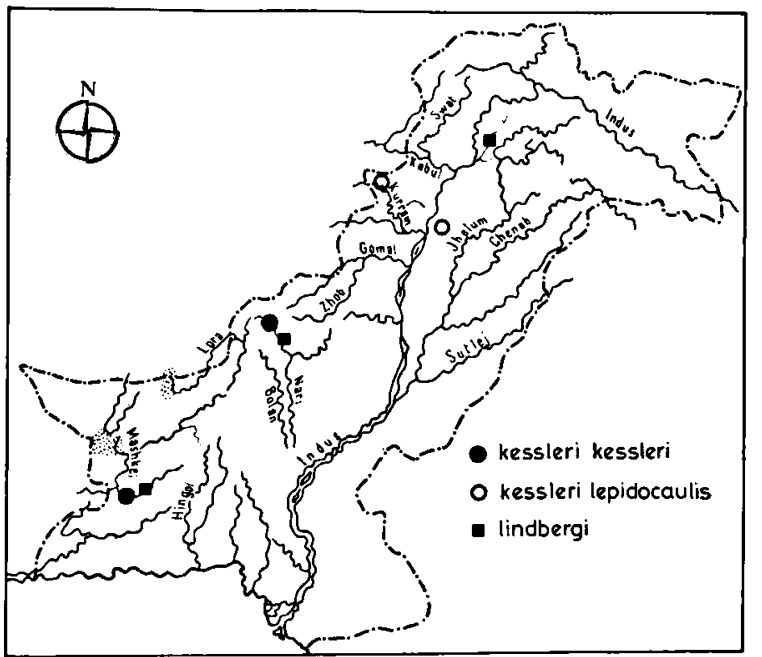

Map 2. Distribution of Schistura kessleri kessleri, $S . k$. lepidocaulis and $S$. lindbergi.

Schistura lindbergi (Banarescu \& Mirza, 1965). Fig. 14.

Noemacbeilus lindbergi Banarescu \& Mirza, 1965: 265, figs. 1-4 (Siaw in the Farah Rud basin, Afghanistan; also Loralai and Panjgur, Pakistan).

The characters of this species and the differences with $S$. kessleri are given in the original description. S. lindbergi also resembles $S$. prashari. However, in the latter species the body is scaled (and also the caudal fin more deeply emarginate). We therefore ascribe $S$. prashari to another species group.
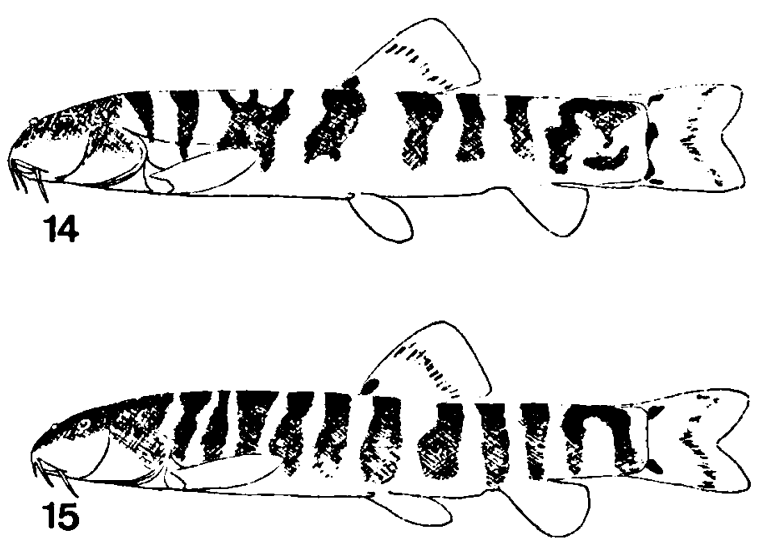

Fig. 14. Sibistura lindbergi, Hebrew University Jerusalem, Pisces, coll. no. 1572, holotype, from rivulet connected to the Farah Rud drainage, Afghanistan. Fig. 15. S. naseeri, ISBB 1235, paratype, from the Madyan River, Swat State. 
Range. - S. lindbergi was collected from the Loralai River, a tributary of the Beji River, that flows southwards and once was a tributary of the lower Indus, from Panjgur on the Rakhshan River, basin of the lake Hamun-i-Mashkel, and from the Unar River near Ugi, a left tributary of the upper Indus (map 2). The occurrence of this species, that lives mainly in the inner drainages west of the lower Indus, in an eastern tributary of the upper Indus is quite unexpected.

\section{Group naseeri-baluchior u m}

The species of this group are characterized by: a small size; rather compressed head (i.e., about as wide as deep); snout pointed in most species, sometimes blunt, always narrowed anteriorly; body scaled, at least in the posterior part; lateral line either short or almost complete; caudal fin forked; processus dentiformis reduced or moderately developed; sexual dimorphism present in most species, absent in a few.

This group seems less natural than the two preceding ones. Its range includes the inner drainages of Pakistan, Afghanistan, Iran, the basins of the Indus, Ganges and Brahmaputra, perhaps also Burma and most of Thailand, but apparently not peninsular India. Most Schistura species from Pakistan can be included within this group.

Schistura naseeri (Ahmad \& Mirza, 1963). Fig. 15.

Noemacheilus punjabensis naseeri Ahmad \& Mirza, 1963: 78, fig. 3 (Madyan stream at Madyan, Swat State).

D $3 / 7$; A $2 / 5$; P $1 / 8-9$.

Body depth 11.7-17.2\% of standard length; least depth 9.2-10.8\%; caudal peduncle length 12.2-15.1\%; predorsal distance 48.0-54.0\%; preventral distance 48.0-56.0\%; pectoral-ventral distance 32.3-38.2\%; ventral-anal distance 21.2$27.0 \%$; length of pectoral fins $17.2-21.2 \%$; head 19.4-22.6\%; snout $6.0-8.1 \%$ (and $31.8-39.0 \%$ of head); eye diameter $3.3-4.4 \%$ of standard length, $13.0-20.0 \%$ of head, and $56.0-72.0 \%$ of interorbital width.

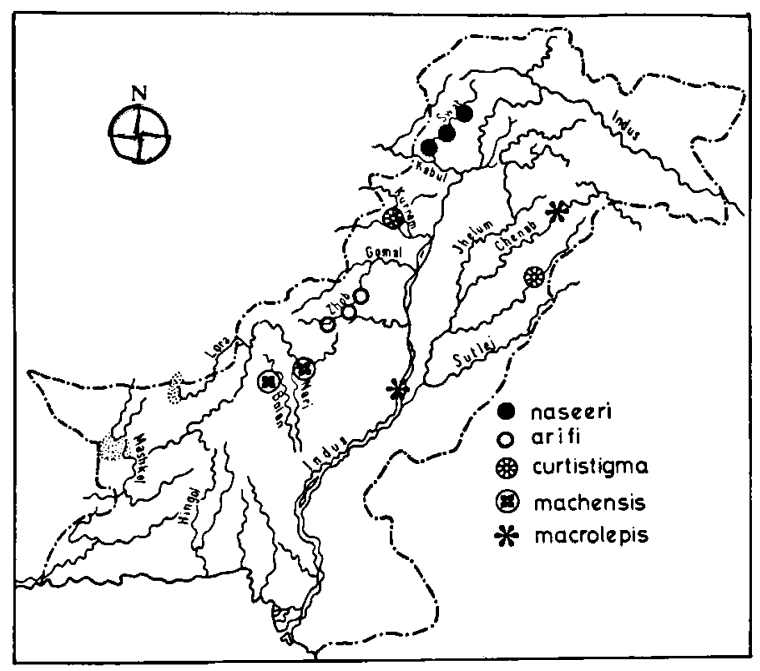

Map 3. Distribution of Schistura naseeri, S. arifi, S. curtistigma. S. machensis and S. macrolepis.

Origin of dorsal fin usually equally distant between tip of snout and base of caudal fin; origin of pelvic fins slightly behind the origin of dorsal fin. Caudal fin forked (shortest rays $59-72 \%$ of longest), with rounded lobes; edge of dorsal fin slightly convex. No membranous connection between ventral fins and lower side of body.

Head slightly wider than deep; snout long, pointed, narrowed anteriorly. Eyes directed laterally.

The scales are embedded; they are few, small, distant and occur only in the posterior body half. The lateral line usually reaches to about twothirds / three-fourths of caudal peduncle, only in a few specimens almost to the caudal fin.

Lips slightly to moderately furrowed; upper one continuous, of uniform width. Processus dentiformis moderate. No sexual dimorphism.

Body light yellowish; 10-12 rather irregular crossbars, usually wider than the interspaces, some of them not sharply delimited. A blackish spot on the origin of the dorsal fin. Bar on caudal fin base in some specimens continuous, in most divided in two fragments. Rays of caudal fin either with a long longitudinal stripe or with two shorter ones.

Range. - Probably endemic to the Swat River basin (map 3); specimens available from Madyan River, Shiner and Mingoara. 
Remarks. - We consider this loach specifically distinct from $S$. punjabensis (Hora), a species ranging in the Salt Range, Punjab, east of the Indus.

Schistura arifi Mirza \& Banarescu, n. sp. Figs. 16-20.

Holotype: ISBB 3775, \& , $60.7 \mathrm{~mm}$ standard length $(62.0 \mathrm{~mm}$ to the end of the scales), Zhob City (formerly Fort Sandeman) on Zhob River, collected by M. Arif.

Paratypes: ISBB 3376, ZMA 116.442 (1), and Mirza's private collection, four specimens, $35.5-70.5 \mathrm{~mm}$, from the Zhob River.

Derivatio nominis. - Named after M. Arif, collector of the specimens.

Diagnosis. - A Schistura species with 8 branched dorsal fin rays; well-marked sexual dimorphism; rather long lateral line, reaching to at least threefourths of caudal peduncle; completely scaled body; upwards directed eyes; some 8-11 crossbars reaching almost to the ventral side; base of ventral fin connected to the body by a thin membrane.
Description. -

D 3/8; A 2/5; P 1/9-10; V 1/6-7.

Dorsal profile behind nape quite slightly arched. Body depth 12.1-16.6\% of standard length $(12.2 \%$ in holotype); caudal peduncle length 12.4-15.9\% (14.6\%); least depth 8.9$9.9 \%(9.8 \%)$; predorsal distance $48.5-51.5 \%$ $(49.5 \%)$; preventral distance $54.0-56.5 \%$ $(54.5 \%)$; preanal distance $75.7-79.5 \%(79.0 \%)$; pectoral-ventral distance $32.9-36.2 \% \quad(32.9 \%)$; ventral-anal distance $20.8-24.8 \% \quad(24.8 \%)$; length of pectoral fins $19.8-23.2 \%(19.8 \%)$; length of ventral fins 20.6-22.4\% (21.2\%); height of dorsal fin 17.8-20.0\%; base of dorsal fin 13.7-17.0\%; height of anal fin 13.7-17.0\%; base of anal fin 7.9-9.4\%; head length 21.0 $25.4 \%(21.4 \%)$; snout length $8.5-10.3 \%$ $(8.6 \%)$ and $38.8-44.0 \%$ of head $(40.0 \%)$; eyc diameter $3.0-4.8 \%$ of standard length $(3.5 \%)$, $14.3-19.0 \%$ of head, $66.7-83.0 \%$ of interorbital width.

Head more or less triangular, slightly com.
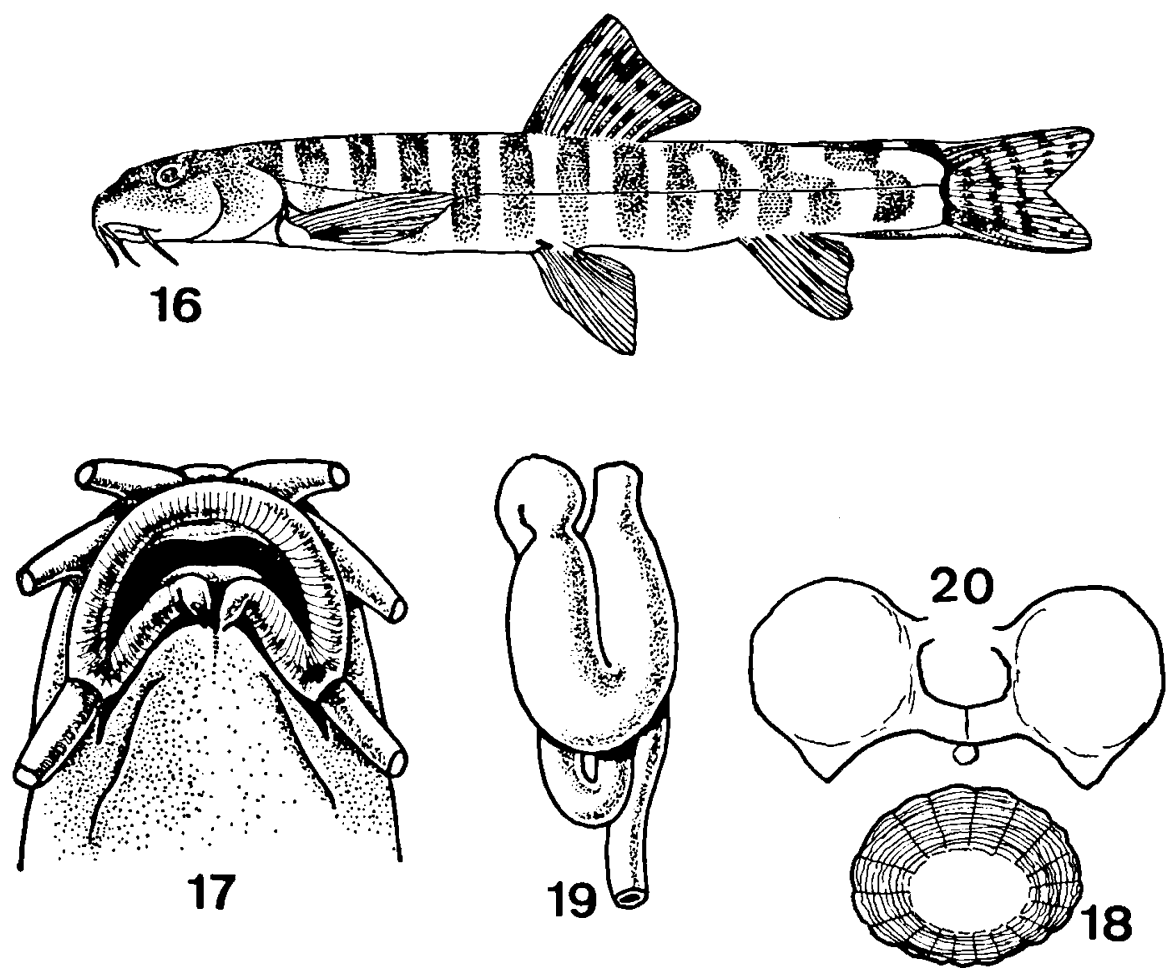

Fig. 16. Schistura arifi n. sp., ISBB 3775, holotype, from the Zhob River at Zhob City. Fig. 17. Do., mouth of holotype. Fig. 18. Do., subdorsal scale of holotype. Fig. 19. Do., digestive tract of a paratype, ISBB 3376. Fig. 20. Do., air bladder capsule of a paratype, ISBB 3376. 
pressed (deeper than wide); snout pointed, narrowed anteriorly. Nostrils closer to the eye than to the tip of the snout. Eyes directed upwards.

Origin of dorsal fin in some specimens equally distant between tip of snout and base of caudal fin; in others closer either to tip of snout or to caudal fin; origin of ventral fins at some distance behind that of dorsal fin. Edge of dorsal fin emarginate. Caudal fin slightly to moderately forked; its shortest (innermost) ray $68-73 \%$ of the longest (outermost); its lobes are pointed. Pectoral fins far from reaching origin of ventral fins; ventral fins almost reaching anal fin insertion. A broad but thin membrane connects the second- or third-last rays of the ventral fins to the lower side of the body.

Scales deeper than long, with a rather large focal zone (fig. 18); they cover most of the body, being absent only on the back in front of the dorsal fin. On the caudal peduncle they are close to each other but not imbricated; in the anterior body half they are distant. The lateral line reaches almost to the caudal fin base or near it.

The lips are moderately furrowed, the upper one continuous (fig. 17). Processus dentiformis moderate.

Loop of the intestine under the stomachic dilatation (fig. 19). The two chambers of the air bladder capsule have a pointed posterior prolongation; the isthmus connecting them is narrow (fig. 20). Peritoneum dark brown.

Sexual dimorphism. - The unique male has a well-developed preocular flap and the second (first branched) pectoral fin ray is thickened; during the spawning season it is probably covered by breeding tubercles. The third (second branched) pectoral fin ray is the longest. In females the third and fourth (second and third branched) pectoral fin rays are equally long.

Colour pattern. - Body light greyish, with 8-11 brownish crossbars reaching from the dorsal almost to the ventral side; they have a regular shape and they are about as wide as the interspaces. A quite evident blackish spot on the origin of the dorsal fin; a continuous dark stripe on the base of the caudal fin; two rows of spots on dorsal, one or two on anal, three to five on caudal fin.
Range. - This species seems to be endemic to the Zhob River basin, tributary to the Gomal River, a right tributary of the middle Indus (map 3); its distribution is the same as that of $S$. pakistanica.

Comparative remarks. - $S$. arifi resembles, in its general habitus and colour pattern, $S$. naseeri; but in $S$. arifi the scales extend over most of the body, there is a sexual dimorphism, the eyes are directed rather upwards and there is a membrane connecting the ventral fin to the lower face of the body. Such a connection also occurs in some other Schistura species and above all in the High Asian genus Triplophysa.

Schistura curtistigma Mirza \& Nalbant, n. sp. Figs. 21-25.

Holotype: ISBB 3776 , ô, $44.8 \mathrm{~mm}$ standard length $(46.0 \mathrm{~mm}$ to the end of the scales), Bannu on the Kurram River, a right tributary of the upper Indus, North.West Frontier Province, Pakistan.

Paratypes: ISBB 3377 and ZMA 116.443 (1), two $q \%$, $34.5(35.0)$ and $33.5(34.5) \mathrm{mm}$, same locality as the holotype.

ISBB 3389, one \%, Ravi River, Lahore, $28.0 \mathrm{~mm}$.

Derivatio nominis. - After curtus = short and stigma $=$ spot, the crossbars being shorter than in the related $S$, arifi.

Diagnosis. - A Schistura species with 7 or 8 branched dorsal fin rays; sexual dimorphism present; almost complete lateral line; body almost totally scaled; some 11 crossbars not extending below lateral line; eyes smaller than in $S$. arifi; long, pointed and convex snout; ventral fin connected to the lower face of the body by a membrane.

Description. -

D 3/7-8; A 2/5; P 1/9-10; V $1 / 7$.

Dorsal profile ascending from tip of snout to above nostrils, then almost horizontal. Body depth $14.5-15.6 \%$ of standard length $(15.6 \%$ in the holotype); least depth $10.9-11.6 \%$ (10.9\%); caudal peduncle length $13.4-14.5 \% \quad(13.6 \%)$; predorsal distance $51.0-54.0 \%$ (51.0\%); preventral distance $54.5-56.5 \%(54.5 \%)$; preanal distance $77.5-80.5 \%(77.5 \%)$; pectoral-ventral distance $33.2-37.0 \% \quad(33.2 \%)$; ventral-anal distance $22.1-23.1 \%(23.0 \%)$; length of pec- 

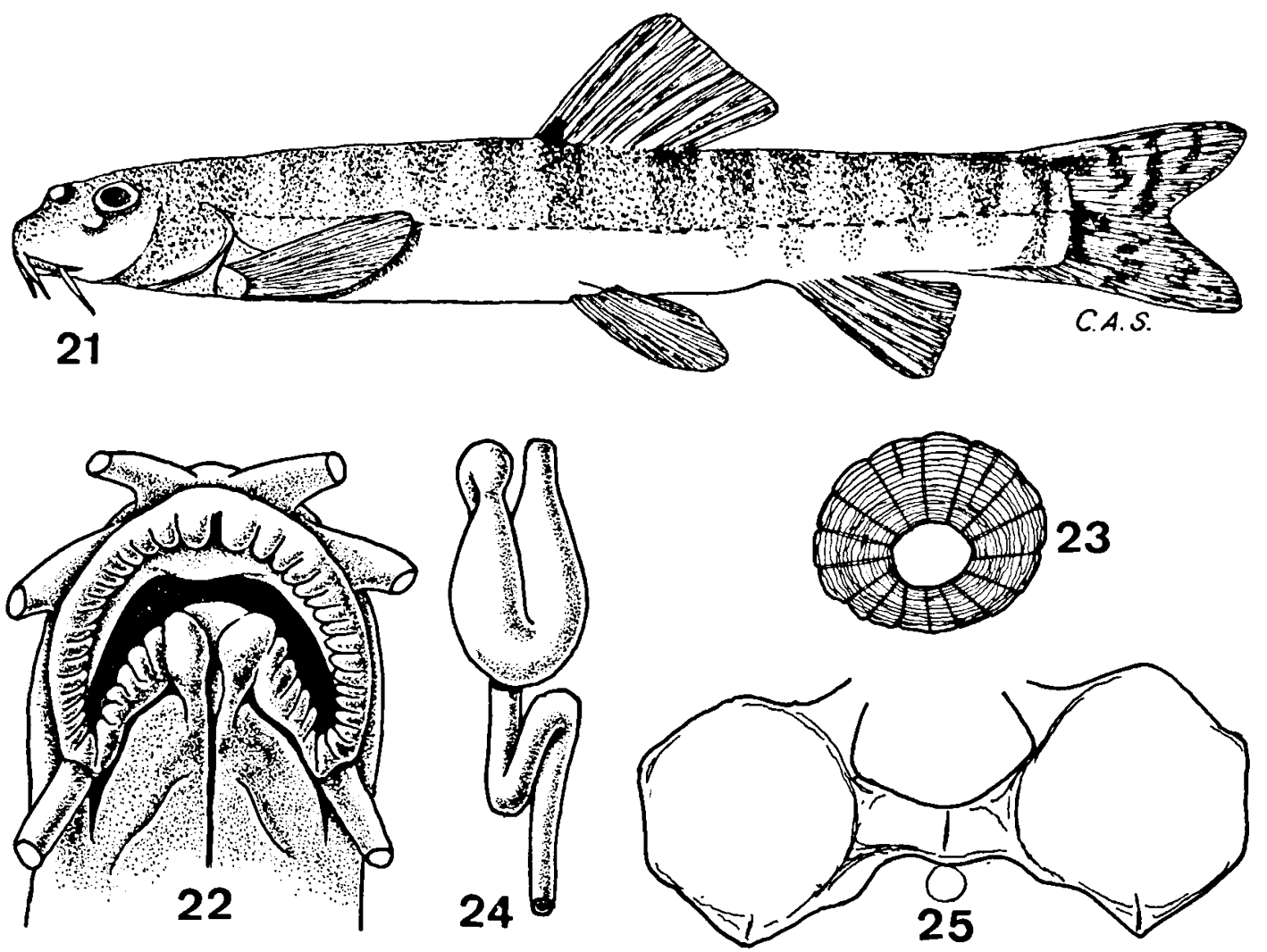

Fig. 21. Schistura curtistigma n. sp., ISBB 3776, holotype, from the Kurram River, Bannu. Fig. 22. Do., mouth of holotype. Fig. 23. Do., subdorsal scale of holotype. Fig. 24. Do., digestive tract of a paratype, ISBB 3377. Fig. 25. Do., air bladder capsule of a paratype, ISBB 3377.

toral fins $20.8-25.0 \%(25.0 \%)$; length of ventral fins $17.8-20.8 \%(20.0 \%)$; height of dorsal fin $17.9-20.5 \%(20.5 \%)$; base of dorsal fin $14.0-$ $15.2 \%(15.2 \%)$; height of anal fin $14.8-17.4 \%$ $(16.1 \%)$; base of anal fin $7.5-9.4 \%(9.4 \%)$; length of head $23.4-27.4 \%$ (23.4\%); length of snout $9.7-11.5 \%$ of standard length $(9.7 \%)$ and $41.0-42.0 \%$ of head $(41.0 \%)$; eye diameter $3.2-$ $3.6 \%$ of standard length $(3.6 \%), 11.6-15.2 \%$ of head $(15.2 \%)$ and $52.5-59.5 \%$ of interorbital width $(59.5 \%)$.

Head slightly wider than deep. Eyes smaller than in other species of the genus, directed upwards. Snout long (especially in the two oㅇ), pointed and convex. Nostrils much closer to the eyes than to the tip of the snout.

Origin of dorsal fin closer to tip of snout than base of caudal fin or equally distant between both; origin of ventral fins behind that of dor- sal fin. Edge of dorsal fin straight. Caudal fin forked, its shortest ray $65.5-74.5 \%$ of the longest; its lobes slightly rounded. Pectoral fins far from reaching the origin of ventral fin; ventral fins reaching or almost reaching to anus, that is a short distance in front of anal fin insertion. A narrow membrane connects the upper side of the ventral fin (second or third inner ray) to the lower face of the body.

Scales deeper than long, with reduced focal zone (fig. 23). They are close to each other on the caudal peduncle (but not imbricated), become more distant anteriorly. They cover most of the body, except the back in front of the dorsal fin. The lateral line reaches almost to the base of the caudal fin.

Lips moderately furrowed, the upper one with a slight median incision (fig. 22). Processus dentiformis reduced. 
Loop of the intestine below the stomachic dilatation (fig. 24). Air bladder capsule similar to that of $S$. arifi (fig. 25). Peritoneum blackish.

Sexual dimorphism. - As in S. arifi.

Colour pattern. - Badly preserved in the specimens available. One can distinguish, with difficulty, about 11 crossbars reaching from the back to the lateral line but not below it. Four rows of minute spots on the caudal fin. A vague dark spot on the origin of the dorsal fin, as in most species of the genus; it is probably better marked in live or well-preserved specimens.

Range. - The species is known from two distant localities in the Indus basin: Bannu on the Kurram River, a right tributary of the upper Indus, and Lahore on the Ravi River, an indirect tributary of the Sutlej River (map 3).

Comparative remarks. - $S$. curtistigma is close to $S$. arifi; its distinctive features are: shorter crossbars, smaller eyes, longer and convex snout.

Schistura machensis (Mirza \& Nalbant, 1970). Fig. 26.

Noemacbeilus horai machensis Mirza \& Nalbant, in Mirza, Banarescu \& Nalbant, 1970: 54, figs. 7-9 (Mach River, tributary to the Bolan River; also Harnai, Kaman Beji basin).

This species has 7 or 8 branched dorsal fin rays, an incomplete lateral line, ending above ventral fins or anal fin; scales with a rather large focal zone and extending on the anterior part of the body; short and pointed snout; reduced processus dentiformis; sexual dimorphism present; loop of the intestine longer than in other Schistura species,

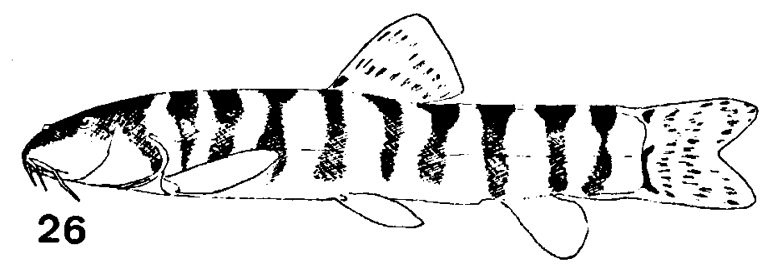

Fig. 26. Schistura machensis, ISBB 1538, holotype, from the Mach River, tributary of the Bolan River, Indus drainage. partially under the stomachic dilatation; the two halves of the air bladder capsule rounded posteriorly and pointed anteriorly; 8-10 wide brownish crossbars, extending below lateral line; brownish bar on base of caudal fin interrupted; moderately forked caudal fin with roundish lobes.

Range. - Basins of Bolan and Kaman-Beji (tributaries of Nari) rivers, both ending in lake Bolan Nari, inner drainage (map 3 ).

We now consider this loach as specifically distinct from $S$. horai (Menon) that ranges in the Kangra Valley, Punjab, eastern part of the Indus basin.

Schistura macrolepis Mirza \& Banarescu, n. sp. Figs. 27-31.

Holotype: ISBB 3778, \& , $29.5 \mathrm{~mm}$ standard length $(30.0 \mathrm{~mm}$ to the last scales), collected by M. Sadiq at Racki Munh, Dera Ghazi Khan district, a small right tributary of the Indus upwards from the confluence of the Sutlej River.

Paratypes: ZMA 116.444 (1), and Mirza's private collection, same data as the holotype, one $\hat{\delta}, 29.0 \mathrm{~mm}$ and one $\&$, $27.8 \mathrm{~mm}$; ISBB 3867 , one $\hat{o}, 36.0 \mathrm{~mm}$, Shadiwal, upper reach of the Chenab River, a tributary of the Sutlej River.

Derivatio nominis. - After $\mu \alpha x p o ́ s=$ large and $\lambda \varepsilon \pi i_{\zeta}=$ scale.

Diagnosis. - A Schistura species with eight branched dorsal fin rays; large scales covering the whole body; almost complete lateral line; sexual dimorphism present; some 8 or 9 irregular crossbars, reaching below lateral line but not to the ventral side; forked caudal fin; the stripe on caudal fin base interrupted; a slight adipose keel on caudal peduncle; long and pointed snout.

Description. -

D 3/8; A 2/5; P 1/8; V 1/6.

Upper profile slightly arched. Body depth $13.9-16.0 \%$ of standard length $(16.0 \%$ in the holotype); least depth $12.3-12.9 \%$ (12.5\%); caudal peduncle length $12.4-13.8 \%(12.6 \%)$; predorsal distance $50.0-55.0 \%$ ( $53.5 \%)$; preventral distance $52.8-55.8 \%(55.8 \%)$; preanal distance $78.0-81.0 \%(81.0 \%)$; pectoral-ventral distance $30.6-34.2 \%(30.6 \%)$; ventral-anal distance $23.8-25.6 \%(23.8 \%)$; length of pectoral fins $23.4-27.1 \%(27.1 \%)$; length of ventral fins 

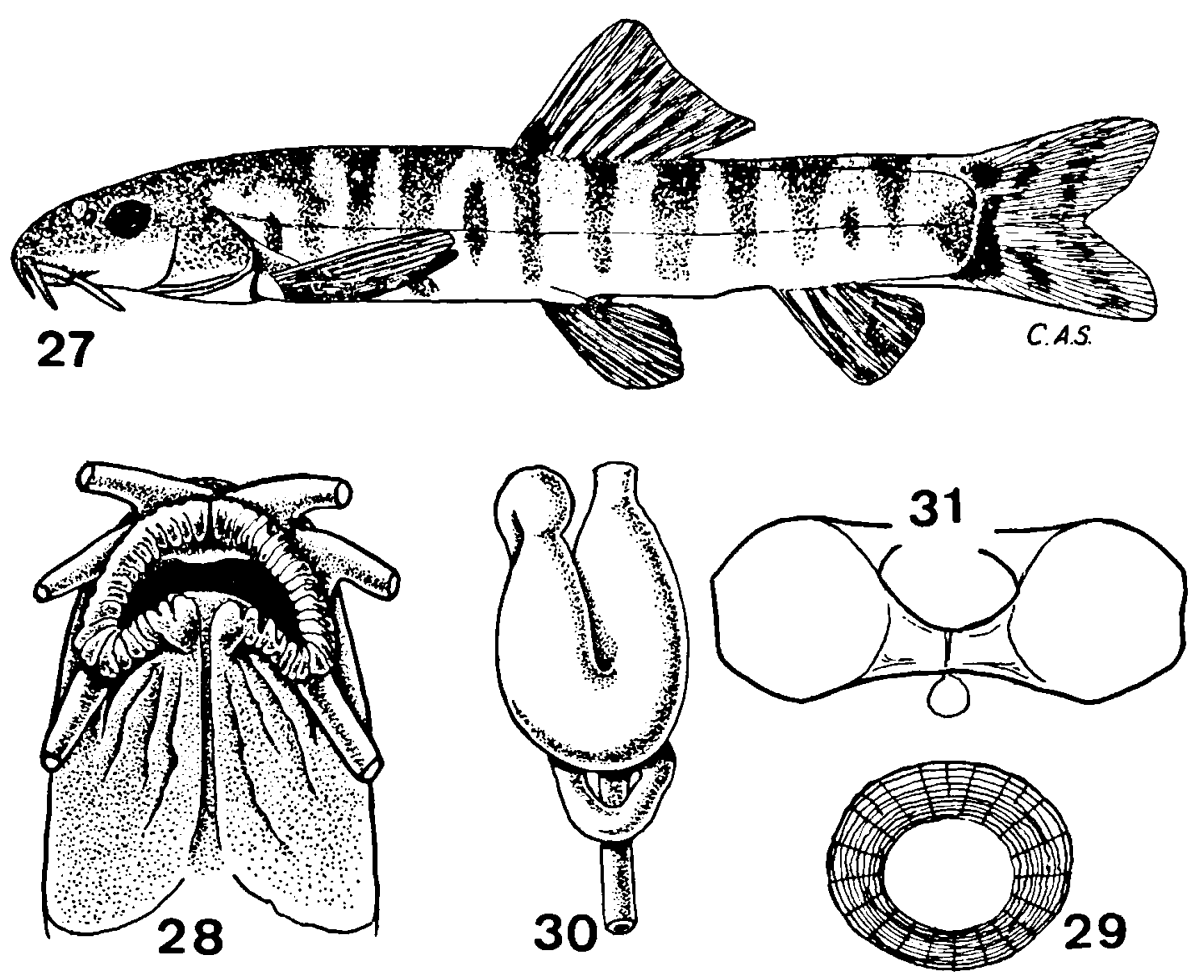

Fig. 27. Schistura macrolepis n. sp., ISBB 3778, holotype, from Racki Munh, Dera Ghazi Khan district, Indus drainage. Fig. 28. Do., mouth of holotype. Fig. 29. Do., subdorsal scale of holotype. Fig. 30. Do., digestive tract of paratype from the type-locality, Mirza's private collection. Fig. 31. Do., air bladder capsule of paratype from the type locality, Mirza's private collection.

21.4-23.6\% (23.4\%); height of dorsal fin 20.7$23.0 \%(23.0 \%)$; base of dorsal fin $14.4-16.9 \%$ $(16.9 \%)$; height of anal fin $15.8-16.7 \%$ $(16.3 \%)$; base of anal fin $8.3-10.3 \%(9.5 \%)$; head length $24.4-25.2 \%(25.1 \%)$; snout length $8.4-10.1 \%(9.5 \%)$ and $37.4-41.2 \%$ of head $(37.8 \%)$; eye diameter $4.0-4.5 \%$ of standard length $(4.4 \%), 16.2-18.2 \%$ of head $(17.5 \%)$ and $68.5-73.0 \%$ of interorbital width $(68.5 \%)$.

Head slightly wider than deep. Snout long, pointed, narrowed anteriorly. Eyes small, directed rather laterally.

Origin of dorsal fin slightly closer to base of caudal fin than to tip of snout or equally distant between both; origin of ventral fins slightly behind that of dorsal fin. Edge of dorsal fin emarginate. Caudal fin forked, its shortest ray 68.5$73.5 \%$ of the longest; lobes of caudal fin rounded. Pectoral fins not reaching ventral origin, ventral fins reaching or almost reaching the origin of the anal fin. Anus slightly in front of anal fin. A dorsal adipose crest on the caudal peduncle.

Scales large, with wide focal zone (fig. 29); they cover the whole body, being imbricated in the posterior body part. Lateral line reaching almost to base of caudal fin.

Lips furrowed, upper one with a median incision (fig. 28); processus dentiformis moderately developed; no incision on the lower jaw. Loop of the intestine partially covered by the stomachic dilatation (fig. 30). The two halves of the air bladder capsule roundish, wider than long, without prolongation (fig. 31). Peritoneum blackish.

Sexual dimorphism. - The two males have a mobile preocular flap; the second to fourth (first to third branched) pectoral fin rays are thickened; breeding tubercles surely develop during the spawning season; the upper face of the head (not the sides) covered by minute whitish breeding tubercles. 
Colour pattern. - Body light yellowish, with eight to nine brownish crossbars, of irregular shape and unequal size; a few independent spots in the interspaces between the crossbars. A blackish spot on the origin of the dorsal fin. The dark bar on the base of the caudal fin is interrupted, its upper fragment being an independent spot. Two rows of vague spots on caudal fin.

Range. - S. macrolepis was found in two localities lying on both sides of the middle Indus: Racki Munh on a small right tributary of the Indus, opposite to the confluence of the Sutlej River and Shadiwal, upstream on the Chenab River, the main tributary of the Sutlej River. The species probably lives throughout most of the Sutlej basin (map 3).

Comparative remarks. - S. macrolepis seems closest to $S$. machensis from the inner drainages of Pakistan, west of the Indus, about at the level of the lower Sutlej River. S. machensis differs from macrolepis in having seven branched dorsal fin rays, shorter snout, smaller eyes, incomplete lateral line (reaching only to the level of the ventral fins or anal fin), and no breeding tubercles on the top of the head. It must be pointed out that, according to our present knowledge, macrolepis is the only Scbistura species having breeding tubercles on the upper face of the head.

\section{Schistura baluchiorum (Zugmayer, 1912).}

Fig. 32.

Nemacbilus balucbiorum Zugmayer, 1912: 599 (Panjgur, Baluchistan); Zugmayer, 1913: 31 (Panjgur); Hora, 1933a: 185 , pl. V figs. 6, 7 (Panjgur).

Noemacheilus baluchiorum; Mirza, Banarescu \& Nalbant, 1970: 48, figs. 1-3 (Panjgur).

Not Noemacheilus baluchiorum, Banarescu \& Nalbant, 1966: 177, figs. 15, 17 (Kajkai, Helmand River basin, southern Afghanistan).

This species is characterized by 7 branched dorsal fin rays; subcylindrical body; long snout; roundish scales with a wide focal zone; lateral line reaching in most specimens to above the anal fin (in a few ones only to above the ventral fins); 11-14 brownish crossbars that extend far below the lateral line, becoming narrower downwards and being
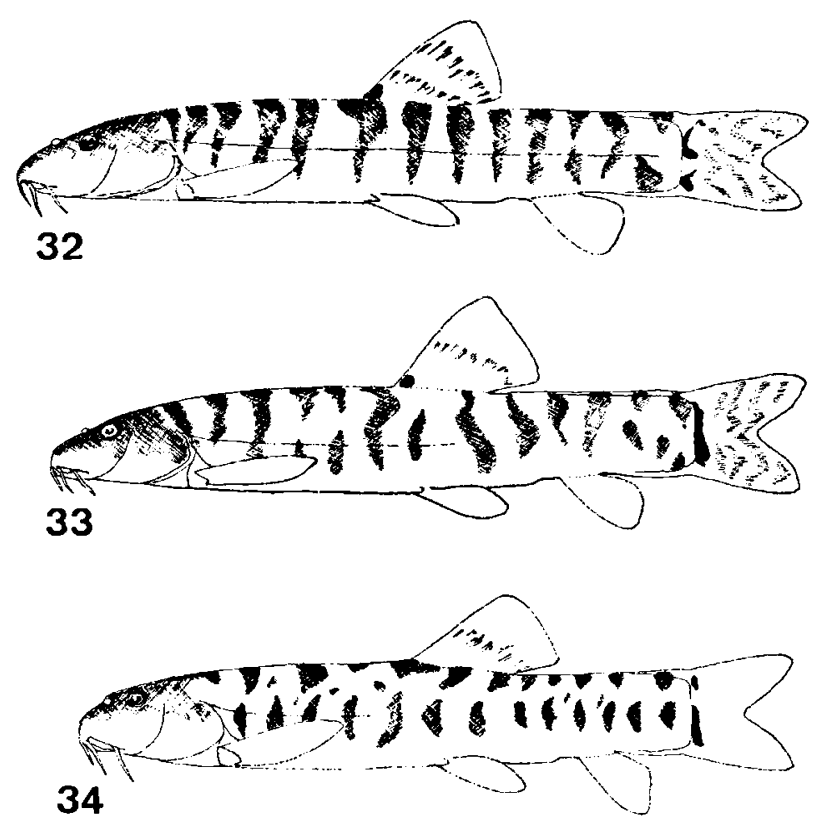

Fig. 32. Schistura balucbiorum, ISBB 1537, from Panjgur, Rakhshan River. Fig. 33. S. anambarensis, ISBB 1364, holotype, from the Anambar River at Loralai. Fig. 34. S. barnaiensis, ISBB 2006, from Harnai, Kaman-Beji River basin.

about as broad as or somewhat narrower than the light interspaces. There is sexual dimorphism. The upper lip is continuous, somewhat broader medially; the processus dentiformis is reduced. The loop of the intestine is wide and touches the stomachic dilatation. The two halves of the air bladder capsule have a pointed posterior prolongation and the manubrium connecting them is wide.

Range. - The species was up to now recorded only from Panjgur on the Rakhshan River, lake Hamun-i-Mashkel basin, inner drainage of Baluchistan. We have also a specimen from Harnai, Kaman-Beji basin, inner drainage (map 4). This specimen does not seem to differ from the many available ones from Panjgur.

Schistura anambarensis (Mirza \& Banarescu, 1970). Fig. 33.

Noemacheilus anambarensis Mirza \& Banarescu, in Mirza, Banarescu \& Nalbant, 1970: 51, figs. 2-6 (Anambar River near Loralai).

This species has 7 branched dorsal fin rays; subcylindrical body; long and pointed snout; incom- 


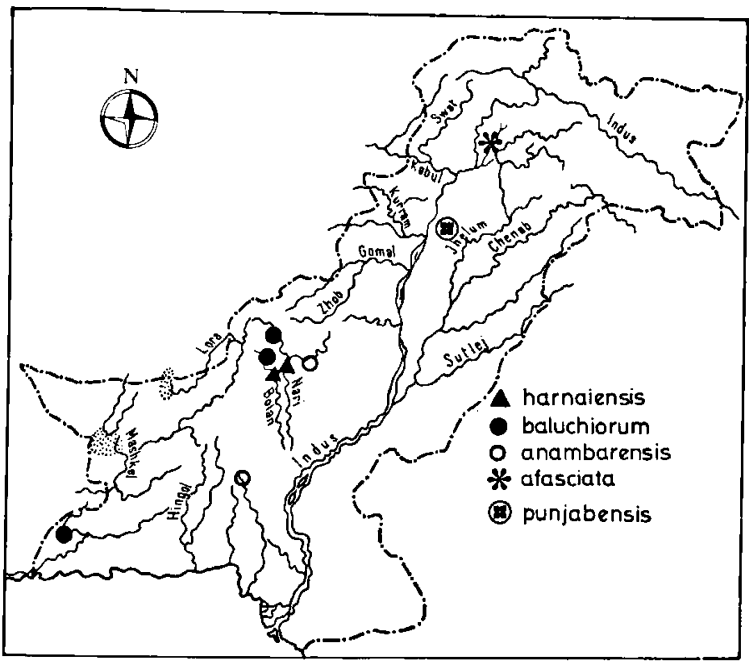

Map 4. Distribution of Schistura barnaiensis, S. baluchiorum, S. anambarensis, S. afasciata and S. punjabensis.

plete lateral line (ending under or in front of dorsal fin); rather circular scales with moderately large focal zone, imbricated posteriorly; reduced processus dentiformis; sexual dimorphism present; long loop of the intestine, touching the stomachic dilatation; the two halves of the air bladder capsule with both an anterior and a posterior pointed prolongation; forked caudal fin; narrow, rather irregular crossbars, some of them incomplete.

Range. - $S$. anambarensis is known from two localities, both in the inner drainage west of the Indus: the Anambar River near Loralai (typelocality) in the basin of the Nari River, that flows in the lake Nari-Bolan, and the Sasol River at Khuzdar, Kolachi River basin (map 4). This is the first record of the species from a second locality.

Remarks. - $S$. anambarensis is very close to $S$. baluchiorum, differing from it in its shorter lateral line (but in one baluchiorum from Panjgur the lateral line is as short as in anambarensis) and the shape of the air bladder capsule. Since baluchiorum occurs, besides in the lake Hamun-i-Mashkel basin, also in the basin of the Kaman Beji River, thus in a river basin close to the range of anambarensis, we consider both loaches a distinct species, not as subspecies of one another.
Schistura harnaiensis (Mirza \& Nalbant, 1969). Fig. 34.
Noemacheilus barnaiensis Mirza \& Nalbant, in Mirza, Bana- rescu \& Nalbant, 1969: 89, pl. II figs. 4-6 (Harnai, Ka- man-Beji basin).

This species has 7 branched dorsal fin rays; incomplete lateral line, ending behind the vertical from the tip of the pectoral fins or under the base of the dorsal fin; minute scales, present over most of the body, with a reduced focal zone; moderately developed processus dentiformis and no incision on the lower jaw; loop of the intestine below stomachic dilatation; the two halves of the air bladder capsule wider than long and rounded; sexual dimorphism present; forked caudal fin; reduced and short adipose crest on caudal peduncle; no true crossbars, but distinct dorsal and lateral spots that do not exactly correspond.

Range. - The species is up to now known only from Harnai, in the basin of the Kaman Beji River, that continues as the Nari River, ending in the lake Nari-Bolan, inner drainage of Pakistan, west of the Indus (map 4).

Schistura afasciata Mirza \& Banarescu, n. sp. Figs. 35-39.

Holotype: ISBB 3368, ô, $37.2 \mathrm{~mm}$ standard length $(37.9 \mathrm{~mm}$ to last scale), Havelian on the Dor River, left tributary of the upper Indus in northern Pakistan.

Derivatio nominis. - After $a=$ without, and fascia $=$ bar, because of the absence of crossbars.

Diagnosis. - A Schistura species with 8 branched dorsal fin rays; almost completely scaled body; lateral line reaching almost to the base of the caudal fin; sexual dimorphism present; forked caudal fin; no crossbars, but back uniformly brownish-grey.

Description. -

D $3 / 8 ;$ A $2 / 5 ;$ P $1 / 9 ;$ V $1 / 8$.

Body of rather uniform depth. Body depth $15.6 \%$ of standard length; least depth $11.4 \%$; caudal peduncle length $11.9 \%$; predorsal distance $54.0 \%$; preventral distance $56.4 \%$; preanal 

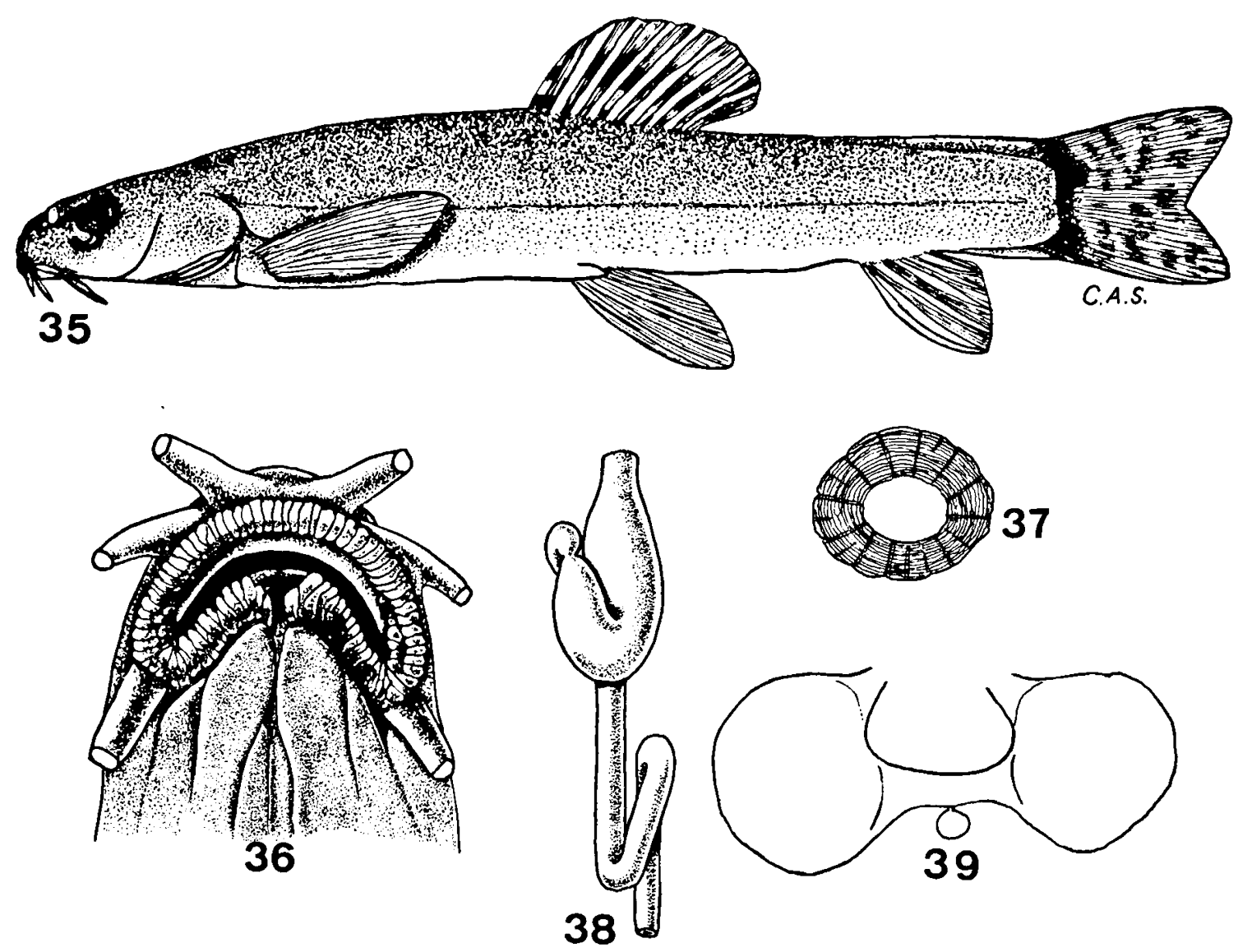

Fig. 35. Schistura afasciata n. sp., ISBB 3368, holotype, from Havelian, Dor River, Indus basin. Fig. 36. Do., mouth of holotype. Fig. 37. Do., subdorsal scale of holotype. Fig. 38. Do., digestive tract of holotype. Fig. 39. Do., air bladder capsule of holotype.

distance $80.5 \%$; pectoral-ventral distance $33.5 \%$; ventral-anal distance $25.6 \%$; length of pectoral fins $23.8 \%$; length of ventral fins $21.7 \%$; height of dorsal fin $20.6 \%$; base of dorsal fin $18.5 \%$; head length $23.8 \%$; snout length $8.4 \%$ (and $35.8 \%$ of head); eye diameter $4.85 \%$ of standard length, $20.0 \%$ of head, $72.0 \%$ of interorbital width.

Head slightly wider than deep. Snout long, pointed; eyes directed laterally.

Origin of dorsal fin closer to the base of the anal fin than to the tip of the snout; origin of ventral fins behind that of dorsal fin. Edge of dorsal fin slightly convex. Pectoral fins not reaching ventral fin insertion, ventral fins not reaching anus; anus slightly in advance of origin of anal fin.

Scales (fig. 37) slightly imbricated posteriorly, distant in the middle of the body, absent in the anterior third. Lateral line long, reaching almost to caudal fin base.

The lips are rather strongly furrowed for a Sibistura (fig. 36), the upper one is continuous, without median incision. Processus dentiformis vaguely indicated. Intestine rather long, its loop far below the stomachic dilatation (fig. 38). The two chambers of the air bladder capsule are rounded; the manubrium is narrow (fig. 39). Peritoneum dark brown.

Sexual dimorphism. - The only specimen on which this species is based is a male; it has a preocular flap, the second (first branched) pectoral ray is widened, thickened and covered by breeding tubercles arranged on plates; the third and fourth 
rays are covered by breeding tubercles too, but they are not widened.

Colour pattern. - Back uniformly light greyishbrown; no crossbars or longitudinal stripe, but a vertical bar on base of caudal fin; a slight brownish spot on origin of dorsal fin; a row of spots near the middle of each dorsal fin ray; vague spots on caudal fin; other fins unspotted.

Range. - Known only from the type-locality on the Dor River (map 4).

Remarks. - This species seems close to $S$. harnaiensis; both have the same habitus, same shape of the lips, etc; but harnaiensis has only seven branched dorsal fin rays, a shorter lateral line, and crossbars. It must be pointed out that harnaiensis is the only Scbistura in the area that has interrupted crossbars, this fact indicating a trend towards their reduction; since in afasciata the crossbars have completely vanished, this species can be considered apomorphic. But, in respect of the length of the lateral line, afasciata, with its complete lateral line, is plesiomorphic, harnaiensis apomorphic.

Schistura prashari (Hora, 1933). Fig. 40.

Nemachilus prashari Hora, 1933b: 189 (275 m north of Kohat City, on the Kohat Toi River, a small right tributary of the Indus).

We identified as $S$. prashari specimens from the Swat River basin, from Rawalpindi and Hasanabdal on the Haro River, from the Sün Sakesar Valley and from Ali Masjid (Khyber Pass, on the Kabul River).

These specimens are characterized by:

D 3/7; body depth $14.5-17.8 \%$ of standard length $(19.6 \%$ in the single specimen from the Sün Sakesar Valley); least depth 10.2-12.8\%; caudal peduncle length 12.2-17.3\%; predorsal distance 51.0-59.0\%; preventral distance 53.0$57.0 \%$; pectoral-ventral distance $30.5-39.0 \%$; ventral-anal distance 23.5-28.5\%; head length 22.9-27.0\%; snout length $6.8-9.6 \%$. Caudal fin forked.

Body scaled; lateral line incomplete, reaching under or slightly behind the dorsal fin. Upper lip

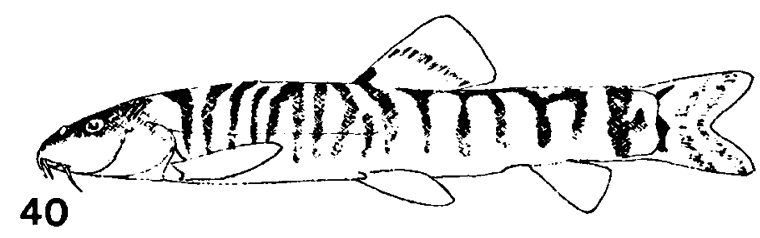

Fig. 40. Schistura prashari, after Hora (1933b), modified.

continuous, moderately furrowed. Loop of the intestine touching the stomachic dilatation. The two chambers of the air bladder capsule with a short posterior prolongation.

Some 12-15 narrow, irregular and unsharply delimited crossbars. A well-marked black spot on the origin of the dorsal fin. Bar on caudal fin base in most specimens continuous, in those from Ali Masjid divided in two spots.

No sexual dimorphism.

Remarks. - The available specimens are similar to $N$. prashari as described and illustrated by Hora, except that they are scaled; Hora mentions the species being scaleless, but he may have overlooked the scales.

Range. - The type-locality lies on the Kohat Toi River, a right tributary of the Indus, south of the Kabul River; we identified as S. prashari specimens from some right tributaries of the Indus (Swat River and Ali Masjid on the Kabul River) and from the Haro River, a left tributary. All these localities, although on both sides of the Indus, are geographically close (map 5).

Schistura fascimaculata Mirza \& Nalbant, n. sp. Figs. 41-45.

Holotype: ISBB 3371, \& $25.0 \mathrm{~mm}$ standard length $(26.0 \mathrm{~mm}$ to the idst scales), Hangu, Kohat district on the Kohat Toi River.

Paratypes: ISBB 3372, ZMA 116.445 (2), and Mirza's private collection, five specimens ( $1 \hat{\delta}$ and $4 q q)$ ), 21.5$26.0 \mathrm{~mm}$, same locality as the holotype.

Derivatio nominis. - After fascia = bar and macula $=$ spot.

Diagnosis. - A small sized Schistura species with 7 branched dorsal rays; few scales present only on 

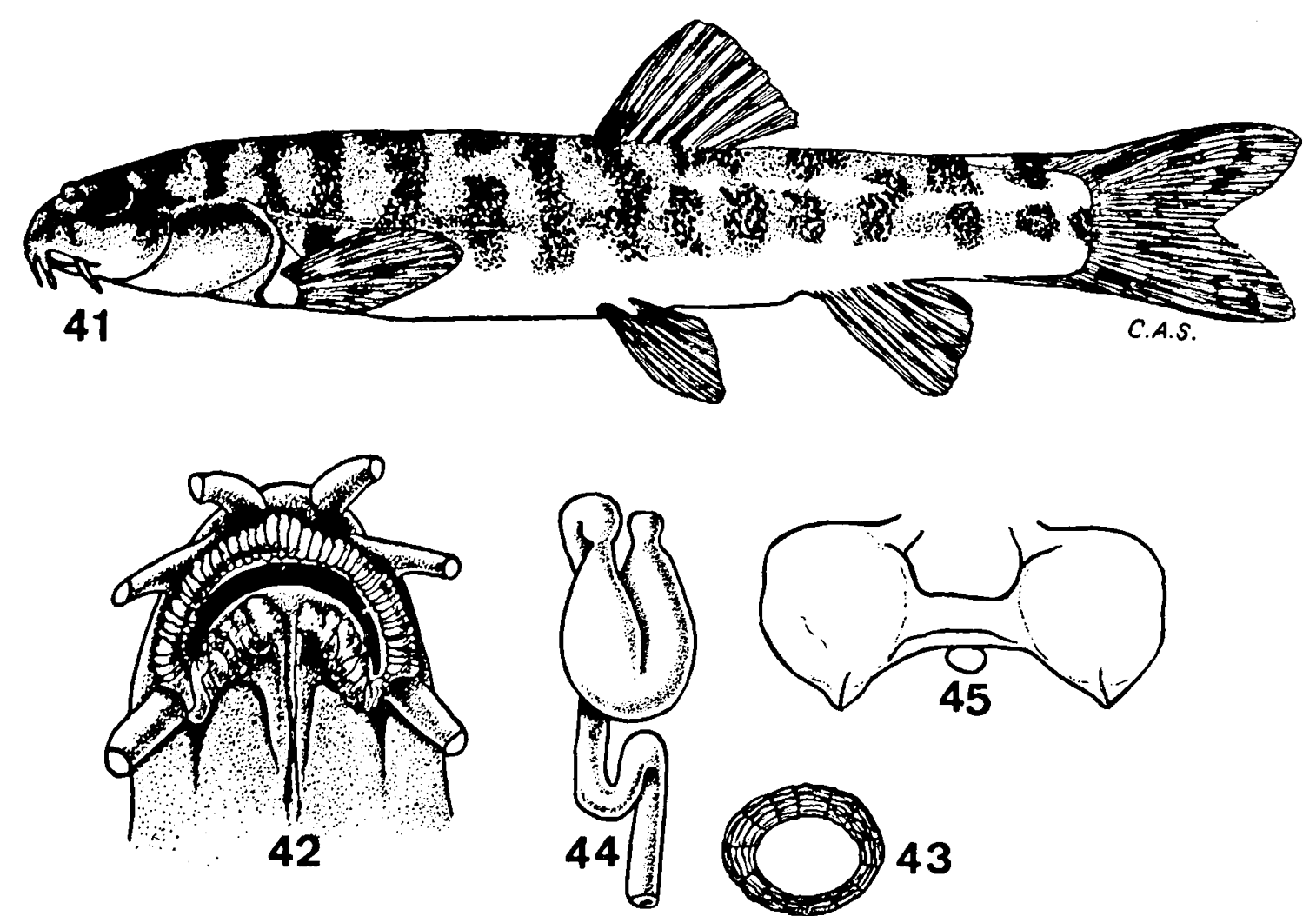

Fig. 41. Schistura fascimaculata n. sp., ISBB 3371, holotype, from Hangu on the Kohat Toi River. Fig. 42. Do., mouth of holotype. Fig. 43. Do., scale from the caudal peduncle of holotype. Fig. 44. Do., digestive tract of a paratype, ISBB 3372. Fig. 45. Do., air bladder capsule of a paratype, ISBB 3372.

caudal peduncle; short lateral line, reaching only above the tip of the pectoral fins; forked caudal fin; body lower than in the sympatric $S$. prashari; sexual dimorphism present; 11-15 crossbars, most of which are interrupted, consisting of a dorsal and a median part, the lateral chambers of the air bladder capsule with a pointed posterior prolongation.

\section{Description. -}

D $3 / 7 ;$ A $2 / 5 ;$ P $1 / 9$; V $1 / 6$.

Dorsal profile convex from tip of snout to nape, almost horizontal behind head. Body depth 13.4$16.0 \%$ of standard length $(16.0 \%$ in the holotype); least depth $8.6-10.8 \%(9.2 \%)$; caudal peduncle length $11.6-13.5 \% \quad(13.7-15.0 \%$ if measured to the last scale); predorsal distance $51.0-53.0 \%$ ( $52.0 \%)$; preventral distance 52.8 $56.5 \%$ (52.8\%); preanal distance $76.0-79.5 \%$; pectoral-ventral distance $31.5-33.0 \%(32.0 \%)$; ventral-anal distance $21.8-24.4 \%(24.0 \%)$; length of pectoral fins $24.0-25.2 \%$; length of ventral fins 19.6-21.3\%; depth of dorsal fin 20.4-22.2\%; base of dorsal fin 13.3-15.5\%; height of anal fin $16.0-19.7 \%$; base of anal fin $8.9-12.3 \%$; length of head $24.0-27.9 \%(24.0 \%$ in the holotype); length of snout $8.4-10.2 \%(8.4 \%)$ and $31.7-$ $37.0 \%$ of head $(35.0 \%)$; eye diameter $4.8-5.3 \%$ of standard length $(4.8 \%), 16.9-20.0 \%$ of head $(20.0 \%)$ and $59.0-78.0 \%$ of interorbital width $(60.0 \%)$.

Head slightly wider than deep; snout moderately blunt, narrowed anteriorly. Nostrils more distant from one another than in other species.

Origin of dorsal fin in most specimens equally distant between tip of snout and caudal fin base, in one specimen closer to caudal fin base; origin of ventral fins slightly behind that of dorsal fin. Edge of dorsal fin slightly convex. Tip of pectoral fins not reaching origin of ventral fins; tip 
of ventral fins usually reaching anal fin insertion, sometimes beyond it. Caudal fin forked (shortest rays $70.5-82.5 \%$ of longest), with rounded lobes.

Scales roundish, with wide focal zone (fig. 43); they are few, isolated, present on the caudal peduncle only. Lateral line short, reaching only above tip of pectorals.

Lips furrowed, anterior one not interrupted (fig. 42). Loop of the intestine not in contact with the stomachic dilatation (fig. 44). The chambers of the air bladder capsule pointed posteriorly (fig. 45). Peritoneum blackish.

Sexual dimorphism. - The only male, probably not fully mature, has a preocular flap, less developed than in other species; the second and third pectoral rays are thickened.

Colour pattern. - Body light greyish, with 11-15 brownish crossbars that, unlike most other Schistura species, are not continuous, but restricted to the middle of the side; on the back there are fewer dorsal spots, not corresponding to the lateral crossbars. Numerous blackish dots occur both on the crossbars and on the interspaces, not extending to the ventral face. A dark spot on the origin of the dorsal fin in some specimens, including the holotype, and an oblique stripe on the base of the two longest rays of the caudal fin; one or two rows of hardly visible spots on the caudal fin.

Range. - Known only from the type-locality on the Kohat Toi River, a small right tributary of the Indus, south of Kabul and north of the Kurrum River (map 5).

Remarks. - This new species shows similarities with $S$. sargadensis from central Iran and with the sympatric $S$. prashari and $S$. kobatensis. The available material of $S$. sargadensis from the $\mathrm{Kul}$ River, southwestern Iran, collected by Dr. P.-G. Bianco, resembles $S$. fascimaculata in general habitus and colour pattern, but has eight branched dorsal fin rays, a less forked caudal fin, and different body proportions. S. prashari from the Swat and Haro rivers has a deeper body and caudal peduncle, shorter lateral line, more numerous scales and no sexual dimorphism. The distinctive characters of $S$. kobatensis are mentioned below.

Schistura kohatensis Mirza \& Banarescu, n. sp. Figs. 46-50.

Holotype: ISBB 3373, of, $30.0 \mathrm{~mm}$ standard length $(30.8 \mathrm{~mm}$ to the last scale), Hangu, Kohat District, on the Kohat Toi River, a small right tributary of the Indus.

Paratypes: ISBB 3374, ZMA 116.446 (2), and Mirza's private collection, four specimens ( $2 \hat{\delta} \hat{\delta}, 2$ q $q), 26.8$. $29.0 \mathrm{~mm}$ standard length $(27.5-30.0 \mathrm{~mm}$ to the last scale).

Derivatio nominis. - From the Kohat District, type-locality.

Diagnosis. - A small species of Schistura with eight branched dorsal fin rays; 10 to 12 more or less regular crossbars extending below lateral line; forked caudal fin; sexual dimorphism present; body almost completely scaled; incomplete lateral line ending below dorsal fin; a quite short adipose crest on the caudal peduncle; dark bar on base of caudal fin interrupted.

Description. -

D $3 / 8 ;$ A $2 / 5 ;$ P $1 / 8-9 ;$ V $1 / 6$.

Body depth 13.1-16.7\% of standard length (16.7\% in the holotype); least depth $9.7-11.7 \%$ $(11.7 \%)$; caudal peduncle length 11.2-14.8\% $(12.0 \%)$; predorsal distance $51.0-53.5 \%$ $(51.5 \%)$; preventral distance $53.5-56.9 \%$ (53.5\%); preanal distance $75.0-82.0 \%$; pectoralventral distance $29.7-33.6 \%(29.7 \%)$; ventralanal distance $23.2-26.0 \%(25.0 \%)$; length of pectoral fins $22.4-26.7 \%(26.7 \%)$; length of ventral fins $18.7-22.2 \%(21.7 \%)$; height of dorsal fin 21.6-27.2\% (21.7\%); base of dorsal fin $14.9-17.9 \%(15.8 \%)$; height of anal fin 16.7$18.3 \%(18.3 \%)$; head length 24.2-26.5\% $(26.4 \%)$; snout length $8.3-10.0 \%(9.3 \%)$ and $34.3-38.4 \%$ of head $(35.4 \%)$; eye diameter $4.5-$ $5.0 \%$ of standard length $(5.0 \%$ in the holotype), $18.3-20.0 \%$ of head $(19.0 \%)$ and $66.7-73.0 \%$ of interorbital width $(71.5 \%)$.

Head slightly wider than deep. Snout long, blunt; eyes directed rather laterally.

Origin of dorsal fin about equally distant between tip of snout and base of caudal fin; origin of ventral fins slightly behind that of dorsal fin. Edge of dorsal fin slightly convex or straight. 

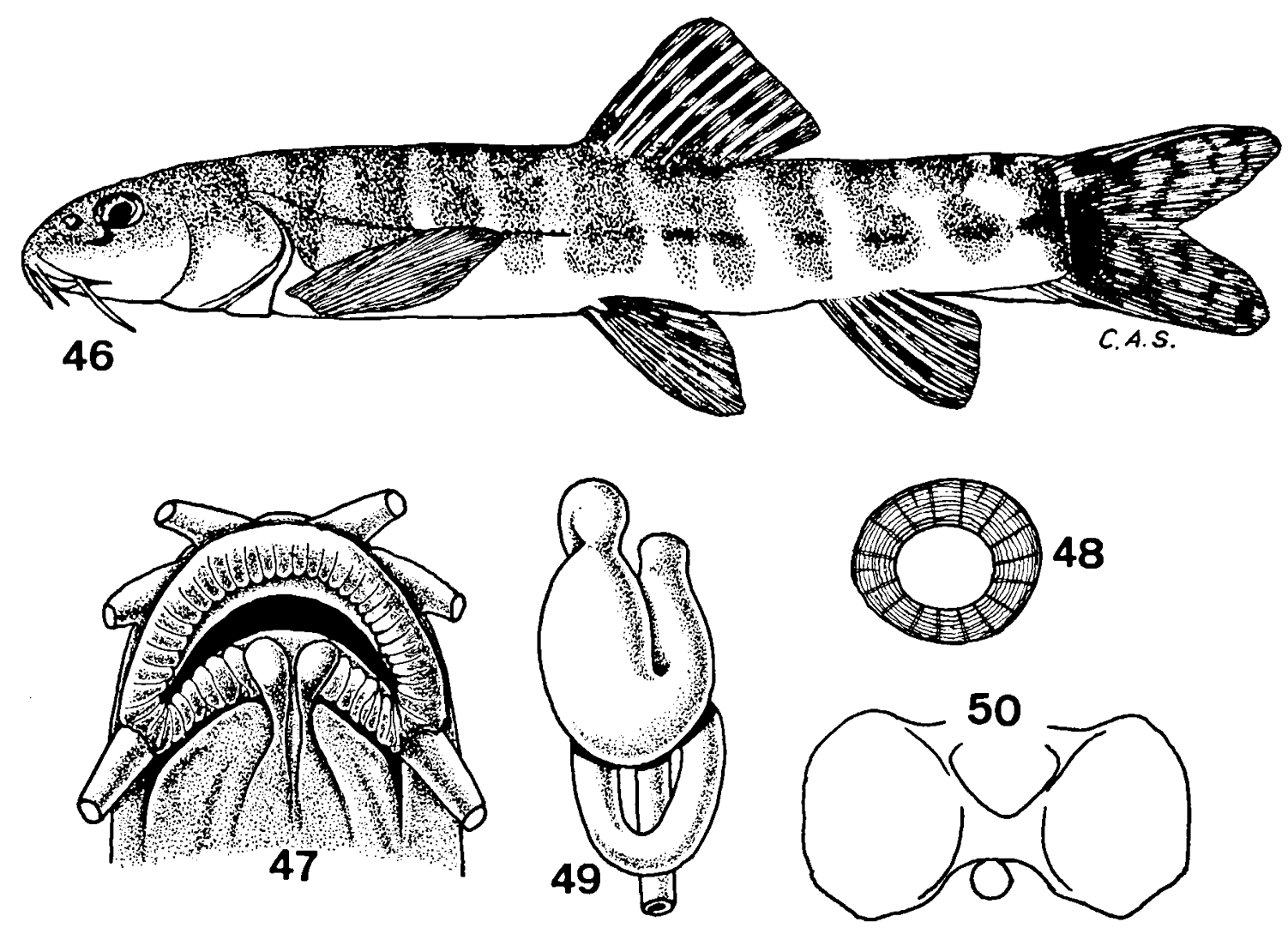

Fig. 46. Schistura kobatensis n. sp., ISBB 3375, holotype, from Hangu, on the Kohat Toi River. Fig. 47. Do., mouth of holotype. Fig. 48. Do., subdorsal scale of holotype. Fig. 49. Do., digestive tract of a paratype, ISBB 3374. Fig. 50. Do., air bladder capsule of a paratype, ISBB 3374.

Caudal fin forked, its shortest ray $69.5-83.0 \%$ of the longest, its lobes rounded. Pectoral fins not reaching the origin of the ventral fin, ventral fins not reaching anal fin. Anus immediately in front of origin of anal fin. Slight indication of adipose crest on caudal peduncle.

Scales almost circular, with reduced focal zone (fig. 48). On the caudal peduncle they are im. bricated; anteriorly they extend along the lateral line to the margin of the opercle, but they are lacking on the back in front of the dorsal fin and on the belly in front of the ventral fins. Lateral line incomplete, ending below anterior or middle part of the dorsal fin.

Lips moderately furrowed; no median incision on the upper lip (fig. 47). Processus dentiformis feeble to moderately developed.

The loop of the intestine touches the stomachic dilatation; its ascending branch longer than in S. fascimaculata (fig. 49). Chambers of the air bladder capsule rounded posteriorly; the manubrium connecting them is short (fig. 50). Peritoneum dark brown.

Sexual dimorphism. - The males have a preocular flap and the second (first branched) pectoral fin ray is thickened; apparently the specimens are not fully mature.

Colour pattern. - Body light whitish-grey; 10 to 12 more or less regular crossbars extend from the back below the lateral line, without reaching the ventral side; they are usually wider than the light interspaces. Sparse dark-brownish dots occur in the interspaces between the crossbars; this is why these are not sharply delimited. There is an irregular and variable bar on the base of the caudal fin, darker than the crossbars; its upper fragment is separated in a distinct spot, as in other species of the genus. A blackish spot on the origin of the 
dorsal fin and two rows of hardly visible spots on the fin itself; irregular spots on the caudal fin, vaguely arranged in four or five rows.

Range. - Known only from the type-locality on the Kohat Toi River, the same as for $S$. fascimaculata (map 5).

Remarks. - This new species, based on apparently half-grown specimens, seems close to S. fascimaculata; it differs from it in the number of dorsal rays, colour pattern, shape of the digestive tract and of the air bladder capsule.

Species isolated within the genus

The two following new species cannot be attributed to any species group of Schistura.
Schistura shadiwalensis Mirza \& Nalbant, n. sp. Figs. 51-55.

Holotype: ISBB 3369, $27.5 \mathrm{~mm}$ standard length, Shadiwal on the Chenab River, a right tributary of the Sutlej River, Indus basin.

Paratypes: ISBB 3370, ZMA 116.447(1), and Mirza's private collection, three specimens, 24.2-27.5 $\mathrm{mm}$, same locality as the holotype.

Derivatio nominis. - After the name of the typelocality.

Diagnosis. - A small-sized Schistura species with eight branched dorsal fin rays; scaled body; almost complete lateral line; forked caudal fin; no sexual dimorphism; eight or nine very regular crossbars connected by a slightly marked median longitudinal stripe; silvery peritoneum.

Description. -

D $3 / 8 ;$ A $2 / 5 ;$ P 1/9-10; V $1 /$.
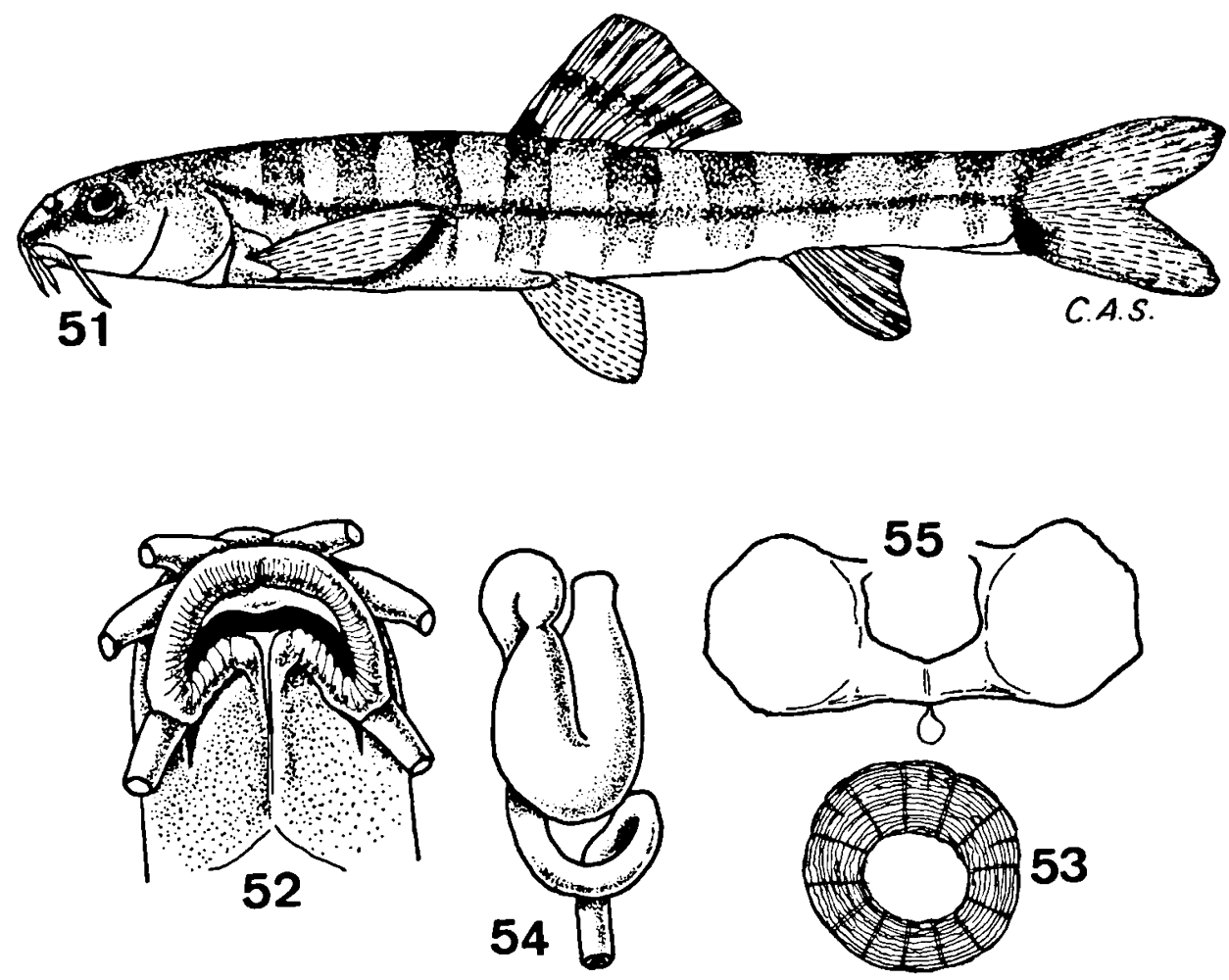

Fig. 51. Schistura sbadiwalensis n. sp., ISBB 3369, holotype, from Shadiwal on the Chenab River. Fig. 52. Do., mouth of holotype. Fig. 53. Do., subdorsal scale of holotype. Fig. 54. Do., digestive tract of a paratype, ISBB 3370. Fig. 55. Do., air bladder capsule of a paratype, ISBB 3370. 
Upper profile slightly convex. Body depth 14.3$16.7 \%$ of standard length $(15.7 \%$ in the holotype); least depth 10.9-11.4\% (10.9\%); caudal peduncle length $15.0-17.1 \%(17.1 \%)$; predorsal distance $49.0-50.1 \%(49.0 \%)$; preventral distance $49.5-52.5 \%$ (51.3\%); preanal distance 76.5$80.0 \%$; pectoral-ventral distance $29.4-32.8 \%$ $(32.8 \%)$; ventral-anal distance $25.5-28.0 \%$ $(25.5 \%)$; length of pectoral fins $23.4-25.1 \%$ $(25.1 \%)$; length of ventral fins $19.3-21.6 \%$ $(21.0 \%)$; height of dorsal fin $19.3-21.6 \%$ $(21.0 \%)$; base of dorsal fin $15.9-18.5 \%$ $(18.5 \%)$; height of anal fin $16.7-18.2 \%$ $(18.2 \%)$; base of anal fin $8.8-11.0 \%(10.6 \%)$; length of head $24.1-26.1 \% \quad(25.1 \%)$; snout length $8.2-8.8 \%(8.7 \%)$ and $31.8-34.8 \%$ of head $(34.8 \%)$; eye diameter $5.1-5.6 \%$ of standard length $(5.1 \%), 20.4-21.6 \%$ of head $(20.4 \%)$ and $66.7-75.0 \%$ of interorbital width $(66.7 \%)$.

Head only slightly wider than deep. Snout pointed.

Origin of dorsal fin usually closer to tip of snout than to base of caudal fin, in one specimen equally distant; ventral fin insertion slightly behind that of dorsal fin. Edge of dorsal fin straight. Caudal fin forked (shortest rays $57-71 \%$ of longest), with rounded lobes. Pectoral fins not reaching insertion of ventral fins, ventral fins not reaching anus; anus slightly in advance of anal fin insertion.

Scales roundish, with large focal zone (fig. 53); they cover most of the body, lacking on back in front of dorsal fin and on breast. Lateral line reaching almost to base of caudal fin, but hardly distinct posteriorly.

Upper lip with a median incision; lower lip rather strongly furrowed (fig. 52).

Loop of the intestine at the level of the posterior margin of the stomachic dilatation (fig. 54). The two halves of the air bladder capsule roundish; the manubrium connecting them is narrow and has a posterior position (fig. 55). Peritoneum silvery.

No sexual dimorphism.

Colour pattern. - Body light greyish-yellow; nine, more rarely eight brownish crossbars on sides, extending almost to the ventral face. They have a uniform width and are about as wide as the yellowish interspaces. Fine dark dots in the interspaces between the crossbars, being more numerous on a longitudinal stripe on the middle of the sides, that extends almost from the opercle to the base of the caudal fin. A vague stripe on head sides, from the eye below the nostrils to the insertion of the inner pair of rostral barbels. A large spot on the lower part of the caudal fin base, present in all specimens; a blackish spot on the origin of the dorsal fin and an oblique row of quite slight spots across the dorsal fin; other fins unspotted.

Range. - Known only from the type-locality, Shadiwal on the upper reaches of the Chenab River, a right tributary of the Sutlej River (map 5); probably endemic to the Sutlej River basin, left tributary of the Indus.

Remarks. - This species bears some similarity to several species of the naseeri group, but is probably not closely related to any of them; its main peculiarities are the silvery peritoneum and the colour pattern.

Schistura microlabra Mirza \& Nalbant, n. sp. Figs. 56-60.

Holotype: ISBB $3869,35.8 \mathrm{~mm}$ standard length $(36.6 \mathrm{~mm}$ to the end of the scales), Ali Masjid, Khyber Pass, Kabul River basin in northern Pakistan.

Paratype: ZMA 116.448, one specimen, $27.2 \mathrm{~mm}$ standard length; Unar River, a small left tributary of the upper Indus near Ugi.

Derivatio nominis. - After $\mu$ « pós $=$ small and labrum $=$ lip, because of the small mouth opening.

Diagnosis. - A Schistura species with depressed head; small mouth; seven branched dorsal fin rays; apparently no sexual dimorphism; few and small scales, present on caudal peduncle only; short lateral line, reaching below dorsal fin only; some 10 crossbars reaching below lateral line; slightly forked caudal fin; stripe on base of caudal fin interrupted.

Description. -

D $3 / 7$; A $2 / 5$; P $1 / 10$; V $1 / 6$.

Dorsal profile slightly arched. Body depth 

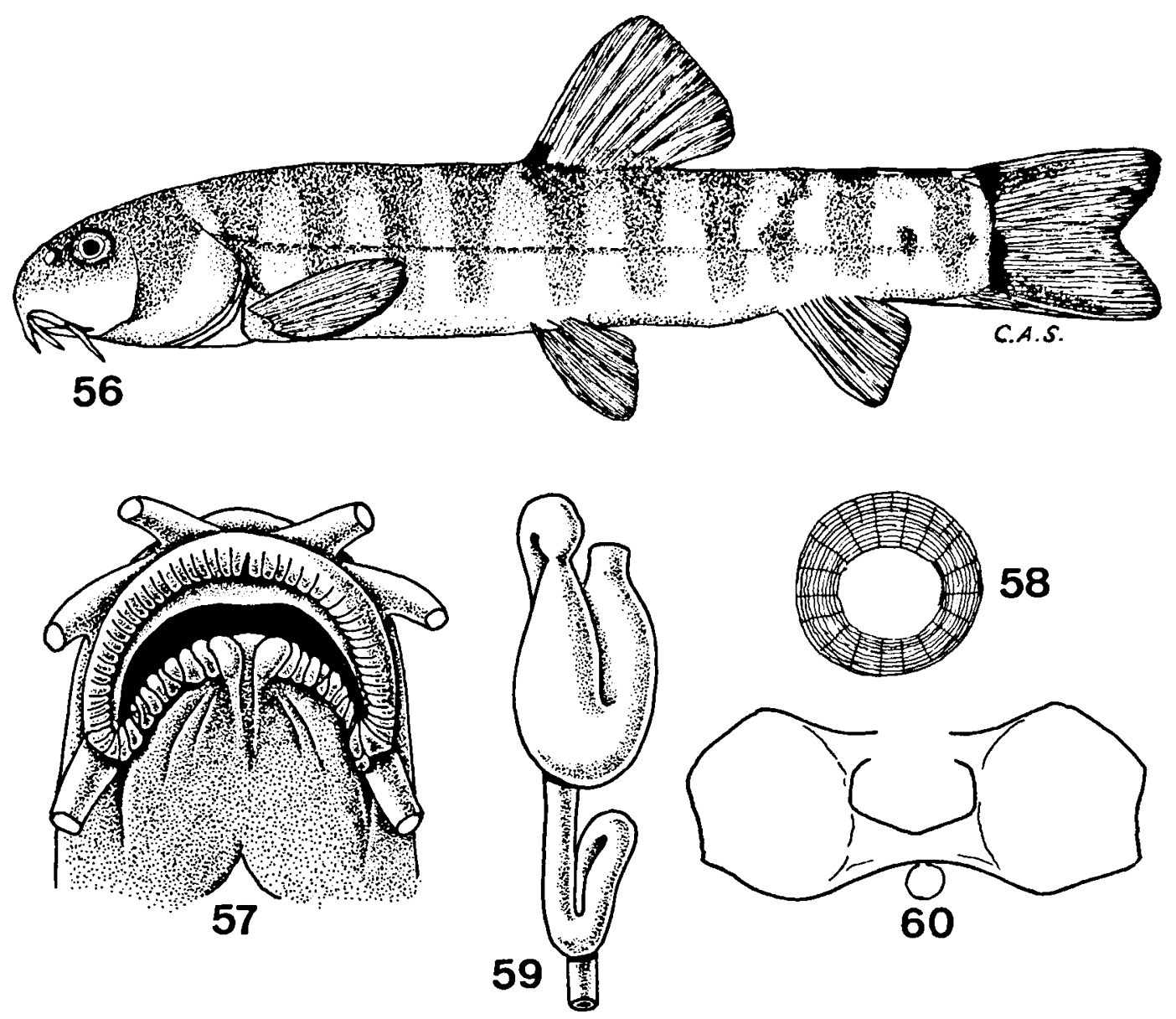

Fig. 56. Schistura microlabra n. sp., ISBB 3869, holotype, from Ali Masjid, Kabul River basin. Fig. 57. Do., mouth of holotype. Fig. 58. Do., scale from caudal peduncle of holotypa. Fig. 59. Do., digestive tract of holotype. Fig. 60. Do., air bladder capsule of holotype.

$17.2 \%$ of standard length in the holotype, $17.7 \%$ in the paratype; least depth 11.9 and $14.0 \%$; caudal peduncle length $14.0 \%$ in both; predorsal distance 56.8 and $56.9 \%$; preventral distance 56.8 and $57.4 \%$; preanal distance 78.0 and $83.5 \%$; pectoral-ventral distance 33.4 and $36.8 \%$; ventralanal distance 26.0 and $25.0 \%$; length of pectoral fins 21.5 and $22.8 \%$; length of ventral fins 16.7 and $18.8 \%$; height of dorsal fin 19.6 and $19.0 \%$; base of dorsal fin 13.4 and $14.7 \%$; height of anal fin 15.7 and $14.7 \%$; base of anal fin 8.1 and $9.9 \%$; head length 22.3 and $25.8 \%$; snout length 8.9 and $9.1 \%$ ( 37.5 and $31.5 \%$ of head); eye diameter 4.2 and $4.8 \%$ of standard length, 18.7 and $18.6 \%$ of head, 51.5 and $59.0 \%$ of interorbital width.

Head depressed, much wider than deep. Snout blunt, narrowed anteriorly. Eyes small and distant, directed upwards.

Origin of dorsal fin closer to tip of snout than to base of caudal fin; origin of ventral fins under or slightly behind that of dorsal fin. Edge of dorsal fin slightly convex. Pectoral fins far from reaching origin of ventral fins, ventral fins far from reaching anal fin. Anus close to origin of anal fin. Caudal fin slightly forked, the shortest ray about $80 \%$ of the longest; its lobes are rounded. Caudal peduncle compressed posteriorly, its dorsal margin sharpened in front of caudal fin base, but without a true adipose keel.

Mouth oblique, smaller than in other species of the genus. Upper lip moderately furrowed, with a quite slight median incision (fig. 57). Processus dentiformis moderate. 
Scales minute, with a large focal zone (fig. 58); they are distant and occur only on the caudal peduncle, being absent anteriorly. Lateral line short, reaching only under base of dorsal fin.

Loop of the intestine below stomachic dilatation (fig. 59). Air bladder capsule without prolongations, with an almost straight posterior margin (fig. 60). Peritoneum dark brown.

Apparently no sexual dimorphism.

Colour pattern. - Light yellowish, with 10 or 11 crossbars of almost uniform width; they are continuous dorsally and extend below the lateral line, without reaching the ventral side. A dark, interrupted bar on the base of the caudal fin, consisting of a dorsal spot and a central and ventral fragment, as in $S$. nalbanti. A dark spot on the origin of the dorsal fin; a vague semilunar blotch on the base of the dorsal fin and vague bars on the margin of both lobes of the caudal fin.

Range. - The two localities where the species was found are distant: Ali Masjid lies in the lower basin of the Kabul River, a right tributary of the Indus, while the Unar River is a small left tributary of the upper Indus, far northeast of the confluence with the Kabul River (map 5).

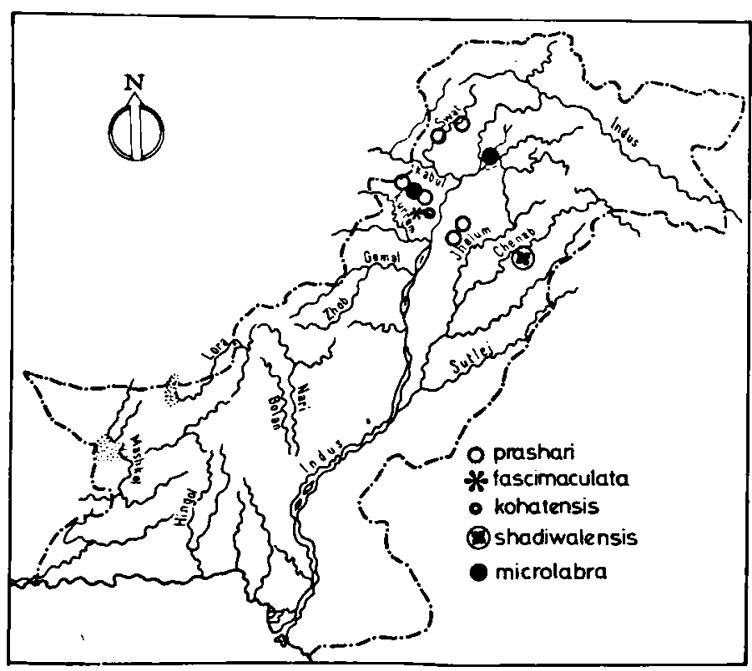

Map 5. Distribution of Schistura prashari, S. fascimaculata. S. kobatensis, $S$. shadiwalensis and S. microlabra.
Comparative remarks. - This new species seems quite isolated within the genus; it resembles both the rupecula and alepidota groups in having a depressed head and a slightly forked caudal fin; but in both groups the lateral line is longer and the processus dentiformis better developed than in microlabra. On the other hand, the species of the rupecula group are almost completely scaled, those of the alepidota group totally devoid of scales, while microlabra has a few scales on the caudal peduncle only, i.e. it is intermediate between the two groups.

No mention is made in this paper of $S$. punjabensis (Hora), a species described from the Salt Range, in the Jhelum River basin, Pakistan (map 4 ), since no specimens were available to us. More Schistura species are expected to be found in Pakistan, besides those described here and punjabensis.

\section{ZOOGEOGRAPHY}

Of the three groups to which the twenty species and one subspecies recorded in this paper belong, one (alepidota-pakistanica) is endemic to the basin of the upper and middle Indus in Pakistan and Afghanistan (more exactly: to the basins of three tributaries of the Indus: the Kabul, Gomal and Sutlej rivers). Another group (kessleri) ranges mainly in the western inner drainages, but also in the Indus basin; the largest group (naseeri-balucbiorum) occurs both in the western drainages and in the Indus basin - and also further east, in the Ganges-Brahmaputra, while the two isolated species have restricted ranges within the Indus basin.

Most species are endemic to restricted areas within the Indus basin, viz. to:

Swat River: naseeri;

Zhob River: pakistanica, arifi;

Kabul River: paludani, microlabra;

tributaries of the Sutlej River: nalbanti, shadiwalensis;

Dor River: afasciata;

Kohat Toi River: fascimaculata and kobatensis; small right tributaries north of the Sutlej confluence: macrolepis; 
Kurram River and Sün Sakesar Valley: kessleri lepidocaulis;

Kurram River and tributaries of the Sutlej River: curtistigma.

Wider ranges within the Indus basin have: S. alepidota (Swat, Kohat Toi and Dor rivers) and especially prashari (Swat, Haro, Kabul rivers, and Sün Sakesar Valley).

Endemic to the inner drainages west of the Indus are: S. kessleri kessleri (most inner drainages of Pakistan, Afghanistan), anambarensis (basins of the Nari and Lora rivers), baluchiorum (Kaman Beji and lake Hamun-i-Mashkel basins) and harnaiensis (Kaman Beji River basin).

A few species are distributed both within the Indus basin and the inner drainages: $S$. kessleri sensu lato (most inner drainages, then Kurram River and Sün Sakesar Valley in the Indus basin), S. lindbergi (basins of Farah-Rud, Beji and Rakhshan rivers, inner drainages, then Unar River, upper Indus basin) and machensis (a tributary of the Bolan River, Indus basin, and Kaman-Beji River basin).

There are four pairs of vicariant species within the naseeri-baluchiorum group:

arifi and curtistigma, both in the Indus basin; barnaiensis (inner drainage) and afasciata (Indus basin), the first one plesiomorphic in respect to the colour pattern, the second in respect to the length of the lateral line;

baluchiorum and anambarensis in the inner drainages; the first one is apparently plesiomorphic in respect to the length of the lateral line;

machensis (inner drainage) and macrolepis (Indus basin); the first one, with an incomplete lateral line, is apomorphic.

The only species that is known to include two subspecies is $S$. kessleri; the nominal subspecies, from the inner drainages, that has lost any traces of scales, is apomorphic in comparison with lepidocaulis from the Indus basin.

Hence, in two cases the taxon from the inner drainages is apomorphic, that from the Indus basin plesiomorphic; in a third case (barnaiensisafasciata), the sister species from the inner drainage is apomorphic in one character, that from the Indus basin in another.

\section{ACKNOWLEDGEMENTS}

The specimens on which the new species $S$. arifi is based, were collected by $\mathrm{Mr}$. M. Arif and presented to the first author. Type material of $S$. kessleri was received on loan from the British Museum (Natural History) through the kindness of Dr. P. H. Greenwood and Mrs. M. Clarke.

Dr. Pier-Giorgio Bianco, L'Aquila, deserves special thanks for the rich collections of freshwater fishes he brought from Iran, which are being studied in collaboration with the second and third author. Comparison with the Iran loaches enabled the authors to clarify the position of some Pakistani species.

The authors also wish to express their sincere thanks to Miss Cristina A. Sirbu for drawing part of the illustrations (marked with C.A.S.).

\section{REFERENCES}

Ahmad, M. F., S. A. Khan \& M. R. Mirza, 1976. A checklist of the freshwater fishes of the Indus Plain, Pakistan. Biologia (Lahore), 22 (2): 229-259.

Ahmad, N. D. \& M. R. MrrzA, 1963. Loaches of the genus Noemacheilus from Swat State, West Pakistan. Pakistan J. Sci., 15: 75-81.

BANAREsCu, P. \& M. R. MirzA, 1965. Noemacheilus lindbergi n. sp., a new loach from Afghanistan and West Pakistan (Pisces, Cobitidae). Senck. biol., 46 (4): 265-269.

— \& 1972. Noemacheilus alepidotus nalbanti nova subsp., a new loach from Rawlakot, Azad Kashmir. Biologia (Lahore), 18 (2): 121-123.

Banarescu, P. \& T. Nalbant, 1966. Cobitidae (Pisces) from Afghanistan and Iran. Vidensk. Medd. dansk naturh. Foren., 129: 149-186.

— \& - 1968. Cobitidae (Pisces, Cypriniformes) collected by the German India Expedition. Mitt. Hamburg. zool. Mus. Inst., 65: 327-351.

- \& —, 1974. The species of Schistura (= Homatula) from the upper Yangtze drainage (Pisces, Cobitidae). Rev. Roum. Biol., 19 (2): 95-99.

BERG, L. S., 1949a. Ryby presnykh vod S.S.S.R. i sopredelnykh stran, 2: 467-925 (Izd. Akademii Nauk, Moskwa/Leningrad).

- $1949 \mathrm{~b}$. Presnovodnye ryby Irana i sopredelnykh stran. Trudy Zool. Inst. Akad. Nauk., 8 (4): 783-858.

BleEker, P., 1863. Atlas ichthyologique des Indes Orientales Néêrlandaises, 3, Cyprins: i-iv, 1-150, pls. I-XLIII (Fréd. Müller, Amsterdam).

GüNTHER, A., 1889. The zoology of the Afghan delimitation commission. Fishes. Trans. Linn. Soc. London, (2, Zool.) 5: 106-109.

HorA, S. L., 1923. Fish of the Salt Range, Punjab. Rec. Ind. Mus., 25: 377-386.

- 1933a. Notes on fishes in the Indian Museum, XX. Loaches of the genus Nemachilus from Baluchistan. Rec. Ind. Mus., 35: 182-188.

- 1933b. Notes on fishes in the Indian Museum, XXI. On a new species of Nemachilus from Kohat, N.W. F. Province. Rec. Ind. Mus., 35: 189-191.

Jordan, D. S., 1919. The genera of fishes, 2. Stanford Univ. Publs., 36: 155-284.

MCClelland, J., 1839. Indian Cyprinidae. Asiatic Researches, 9: 217.465. 
MIRZA, M. R., 1972. Freshwater fishes of Baluchistan Province, Pakistan. Biologia (Lahore), 18: 153-190.

, 1973. Aquatic fauna of Swat Valley, Pakistan, I. Fishes of Swat and adjoining areas. Biologia (Lahore), 19: 119-144.

$\longrightarrow$, 1975. Freshwater fishes and zoogeography of Pakistan. Bijdr. Dierk., 45 (2): 143-180.

- 1976. A checklist of the freshwater fishes of the Indus Plain, Pakistan. Biologia (Lahore), 22: 229-259.

MirzA, M. R. \& M. I. AwAN, 1976. Fishes of the SünSakesar Valley, Punjab, Pakistan, with the description of a new subspecies. Biologia (Lahore), 22: 27-49.

Mirza, M. R., P. Banarescu \& T. T. Nalbant, 1969. Two new loaches of the genus Noemacheilus from West Pakistan. Pakistan J. Zool., 1: 87-90.

_, _ \& \& 1970. A little known and three new loaches of the genus Noemacheilus from West Pakistan. Biologia (Lahore), 16: 47-58.
Nrkolski, A. M., 1900. Presmykaïushtchiasia, amfibii i ryby btorogo putoshestija N.A. Zarudnogo v' Persiu v' 1898 g. Annuaire Mus. zool. Acad. impér. Sci. St. Pétersbourg, 4 (4): 375-417, pl. XX.

Nikolski, G. V., 1947. The loaches of inland waters of Turkmenia. (Russ., English summary). Bull. Soc. Natural. Moscou, (Biol.) 52: 29-34.

OMER, T. \& M. R. MrRzA, 1975. A checklist of the fishes of Hazara District, Pakistan, with the description of a new subspecies. Biologia (Lahore), 21: 199-209.

Valenciennes, A., 1846 (In: G. Cuvier \& A. ValencienNES). Histoire naturelle des poissons, 18: i-xviii, 1-375, pls. 520-553 (P. Bertrand, Paris).

ZUGMAYER, E., 1912. Eight new fishes from Baluchistan. Ann. Mag. nat. Hist., (8) 10: 595-599.

1913. Die Fische von Balutschistan. Abh. k. Bayer. Akad. Wiss., 26: 1-35. 